\title{
Antitrust Law and Regulatory Gaming ${ }^{1}$
}

\author{
Stacey L. Dogan ${ }^{2}$ and Mark A. Lemley ${ }^{3}$
}

Antitrust law promotes competition in the service of economic efficiency. Government regulation may or may not promote either competition or efficiency, depending on both the goals of the agency and the effects of industry "capture." Antitrust courts have long included regulated industries within their purview, working to ensure that regulated industries could not use the limits that regulation imposes on the normal competitive process to achieve anticompetitive ends. ${ }^{4}$ Doing so makes sense; an antitrust law that ignored anticompetitive behavior in any regulated industry would be a law full of holes.

The role of antitrust in policing regulated industries appears to be changing, however. A cluster of Supreme Court decisions in the past decade have fundamentally altered the relationship between antitrust and regulation, placing antitrust law in a subordinate relationship that, some have argued, requires it to defer not just to regulatory decisions but perhaps even to the silence of regulatory agencies in their areas of expertise. ${ }^{5}$ While many of those decisions

1 (C) 2008 Stacey L. Dogan \& Mark A. Lemley.

2 Professor of Law, Northeastern University.

3 William H. Neukom Professor, Stanford Law School; of counsel, Keker \& Van Nest LLP. Thanks to Tim Schneider, research assistant extraordinaire, and to Rose Hagan, Scott Hemphill and participants in a conference at the University of Minnesota School of Law for comments on an earlier draft.

4 See, e.g., Otter Tail Power Co. v. United States, 410 U.S. 366 (1973); Northeastern Tel. Co. v. AT\&T, 651 F.2d 76 (2d Cir. 1981); see generally Philip J. Weiser, The Relationship of Antitrust and Regulation in a Deregulatory Era, 50 Antitrust Bull. 549 (2005).

5 Credit Suisse First Boston Ltd. v. Billing, 127 S.Ct. 2383 (2007); cf. Nynex Corp. v. Discon, Inc., 525 U.S. 128 (1998); Verizon v. Trinko, 540 U.S. 398 (2004). 
might be justified on their facts as a matter of antitrust law, ${ }^{6}$ together they are leading courts and commentators to conclude that the antitrust laws are impliedly repealed by government regulation of a particular industry. ${ }^{7}$ The new vogue for antitrust deference will come to a head in 2009, when the Supreme Court decides Pacific Bell v. linkLine, which raises the question whether a regulated monopoly with franchised rights of way violates the antitrust laws by engaging in a "price squeeze": charging broadband competitors wholesale prices for use of the right of way that exceed the retail prices its own subsidiary charges its customers. ${ }^{8}$

Absolute antitrust deference to regulatory agencies makes little sense as a matter either of economics or experience. Economic theory teaches that antitrust courts are better equipped than regulators to assure efficient outcomes in many circumstances. Public choice theory - and long experience - suggests that agencies that start out trying to limit problematic behavior by industries often end up condoning that behavior and even insulating those industries from market forces. And as history has shown, relying on regulatory oversight alone without the backdrop of antitrust law would leave both temporal and substantive gaps in enforcement, which unscrupulous competitors could exploit to the clear detriment of consumers. ${ }^{9}$ The mere

6 See, e.g., CreditSuisse Securities, LLC v. Billing, 127 S.Ct. 2383, 2390 (2007) (Stevens, concurring) ("I ... would hold ... that the defendants" alleged conduct does not violate the antitrust laws, rather than holding that Congress has implicitly granted them immunity from those laws."). The exception is Trinko, which arguably produced anticompetitive results and which certainly misinterpreted prior law. See infra text accompanying notes ___

7 Bruce H. Kobayashi \& Joshua D. Wright, Federalism, Substantive Preemption, and Limits on Antitrust: An Application to Patent Holdup (working paper 2008); cf. Rambus, Inc. v. FTC, 522 F.3d 456 (D.C. Cir. 2008).

8 linkLine Communications, Inc., v. SBC California, Inc., 503 F.3d 876 (9th Cir. 2007), cert. granted sub nom., Pacific Bell Telephone Co. v. linkLine Communications, Inc., __ U.S. _ , 128 S.Ct. 2957 (2008).

9 Indeed, Trinko itself arguably illustrates the phenomenon of monopolists abusing their position in the face of ineffective regulatory oversight. See generally Spencer Weber Waller, Microsoft and Trinko: A Tale of Two Courts, 2006 UTAH L. REV. 741, 753-55 (2006) 
existence of a competition-conscious regulatory structure cannot guarantee against abuses of that structure, or against exclusionary behavior that falls just beyond its jurisdiction. ${ }^{10}$ Indeed - and perhaps ironically - the very regulatory structure that exists to promote competition can create gaming opportunities for competitors bent on achieving anti-competitive goals. Such "regulatory gaming" undermines both the regulatory system itself and the longstanding complementary relationship between regulatory and antitrust law.

We argue that the risk of regulatory gaming provides an important example of the need for ongoing antitrust oversight of regulated industries. We define regulatory gaming as private behavior that harnesses pro-competitive or neutral regulations and uses them for exclusionary purposes. Complex regulatory systems - particularly those requiring government approval for market entry - can create opportunities for such gaming, by enabling dominant parties to dictate industry standards while delaying entry of competing products. The pharmaceutical industry has witnessed this behavior for years, as branded drug companies have used exclusionary tactics to stay one step ahead of generic entry. In one species of this behavior - product-hopping - the branded company makes repeated changes in drug formulation to prevent generic substitution,

(questioning effectiveness of regulatory regime in Trinko); Adam Candeub, Trinko and ReGrounding the Refusal to Deal Doctrine, 66 U. PITT. L. REV. 821 (2005) ("Trinko's implication that there can be no antitrust injury from refusing to deal, i.e., provide interconnection, so long as regulation requires access, is probably not true.").

10 E.g., Covad Communications Co. v. BellSouth Corp., 374 F.3d 1044, 1050 (11th Cir. 2004) (upholding antitrust claim based on a "squeeze" between regulated wholesale prices and unregulated retail prices that plaintiff claimed were predatory); $c f$. Town of Concord v. Boston Edison Co., 915 F.2d 17, 29 (1st Cir. 1990) (Breyer, C.J.) ("We recognize that a special problem is posed by a monopolist, regulated at only one level, who seeks to dominate a second, unregulated level, in order to earn at that second level the very profits that regulation forbids at the first."). See generally Candeub, supra note _, at 841 ("Congress could quite reasonably have wanted the antitrust laws to enforce its access regime because, for better or worse, the FCC, structurally incapable of Olympian detachment from political influence, could be seen as a poor forum to decide such disputes. Or, at the very least, Congress could have intended the threat of antitrust action to discipline the behavior of the Baby Bells."). 
rather than to improve the efficacy of the drug product. ${ }^{11}$ Product-hopping raises difficult questions for antitrust courts. On the one hand, product hopping antitrust suits require courts to inquire into product design choices, something antitrust judges take pains to avoid; they also raise concerns about courts second-guessing judgments by agencies and legislators about how best to balance competition and innovation in regulated markets. On the other hand, if left unchallenged, this kind of behavior can cause sustained inefficiencies in markets.

Industry standards set or endorsed by government bodies offer a second example. If the government requires that products include particular features or perform in particular ways, private parties can sometimes hoodwink regulators into adopting standards that favor their proprietary technologies and exclude their competitors. ${ }^{12}$ Of course, nothing prevents the government from settling on a patented standard, and private parties have a protected right to petition the government regardless of their motive. But when petitioning behavior contains material misstatements or omissions, and results in standards that exclude competition in ways the government did not anticipate, the petitioning party has abused the regulatory process. Here, too, antitrust courts must strike a delicate balance among several competing concerns - the right to petition the government, the legitimate enforcement of patent rights, and the very real problem of patent holdup and regulatory abuse. ${ }^{13}$

Our goal in this paper is not to persuade the reader that these particular examples of regulatory gaming violate the antitrust laws (though we think they do) or that other examples,

11 FTC v. Warner Chilcott, 2005 WL 3439585 (D.D.C. Complaint Filed Nov. 7, 2005); Abbott Laboratories v. Teva Pharmaceuticals USA, 432 F. Supp. 2d 408 (D. Del. 2006).

12 Opinion of the Commission, In re Matter of Union Oil Company of California, Docket No. 9305 (opinion issued July 7, 2004), available at http://www.ftc.gov/os/adjpro/d9305/040706commissionopinion.pdf.

13 See, e.g.., Mark A. Lemley \& Carl Shapiro, Patent Holdup and Royalty Stacking, 85 Tex. L. Rev. 1997 (2007). 
such as regulatory price squeezes, do not violate the antitrust laws. Rather, our point is that whether or not particular acts of regulatory gaming harm competition is and should be an antitrust question, not merely one that involves interpreting statutes or agency regulations. Regulatory agencies and even Congress cannot prevent gaming ex ante. Experience with the pharmaceutical industry suggests that if Congress acts to squelch one form of gaming, companies will find other ways to game the system. And even if Congress or the regulating body can surgically fix a particular type of exclusionary behavior, such an ex post response (unlike the threat of antitrust treble damages) does nothing to compensate for past harm or to deter future gaming behavior. Some level of antitrust enforcement - with appropriate deference to firm decisions about product design and affirmative regulatory decisions that affect market conditions - provides a necessary check on behavior, such as product hopping, that has no purpose but to exclude competition.

Part I begins with an introduction to the relationship between antitrust law and industryspecific regulation. After briefly discussing the historical collaboration between antitrust and regulatory law, we explore the recent cases that show skepticism toward antitrust intervention in regulated industries - skepticism that represents a marked departure from antitrust history. In Part II, we contend that this skepticism, if applied too broadly, contradicts both logic and a rich economic literature that suggests that antitrust law generally does a better job of disciplining exclusionary behavior and achieving competitive outcomes than do government agencies. The decisions that have ushered in antitrust deference have perverted the lessons of law and economics, taking the efficiency-based attacks lodged against overly vigorous antitrust enforcement as license to cut back on all antitrust enforcement, even where antitrust offers the only hope of curbing regulatory abuse. 
At the same time, we agree that antitrust courts must use caution in treating regulated industries, intervening only when the regulatory structure appears unable, for some identifiable reason, to ensure competitive outcomes. Thus, Part III distills a framework for evaluating the application of antitrust law to regulated industries. While we argue that antitrust should not defer to regulatory agencies merely because they operate in the area of inquiry, neither should antitrust ignore the decisions regulators make. Where a regulator has made a decision that affects competition - by setting a particular price, for example, or denying a license to a potential competitor - antitrust should not second-guess that decision absent evidence of outright corruption. ${ }^{14}$ But the fact that a regulator does not object to or block a private company's anticompetitive practice does not mean that antitrust law must countenance that practice. When regulators lack the mandate or the commitment to protect against exclusionary behavior, antitrust courts have a continuing role to play.

Indeed, the existence of regulation not only fails to guarantee competitive outcomes in many cases, but can make things worse by creating opportunities for anticompetitive games. In Part IV, we turn to regulatory gaming as an example of behavior that justifies ongoing antitrust oversight of regulated markets. We use three examples - pharmaceutical product-hopping, abuse of government standard-setting, and regulatory price squeezes - to illustrate the phenomenon of

14 See, e.g., Federal Prescription Services, Inc. v. American Pharmaceutical Ass'n, 663 F.2d 253, 263 (D.C. Cir. 1981) ("Attempts to influence governmental action through overtly corrupt conduct, such as bribes (in any context) and misrepresentation (in the adjudicatory process), are not normal and legitimate exercises of the right of petition, and activities of this sort have been held beyond the protection of Noerr."); id. at 262 (Noerr is inapplicable to activity that "subverted the integrity of the governmental process"); $c f$. Allied Tube \& Conduit Corp. v. Indian Head, Inc., 486 U.S. 492 (1988) (finding antitrust violation based on wholesale capture of private standard-setting body). See Mark A. Lemley \& David McGowan: Antitrust Immunity: State Action and Federalism, Petitioning and the First Amendment, 17 Harv. J. L. \& Pub. Pol'y 293 (1994). 
regulatory gaming, the risks that gaming can pose to competition and consumer welfare, and the appropriate limits of antitrust in this area. Part V concludes.

\section{The Role of Antitrust in Regulated Industries}

Antitrust is designed to protect competition. ${ }^{15}$ But threats to competition do not come only from private conduct in unregulated industries, the traditional province of the Sherman Act. They can also come from government regulation itself, from government delegation of market control to private actors, and - most important for our purposes - from private actions designed to take advantage of a regulatory regime.

Courts have long recognized the potential for conflicts between an antitrust regime directed at encouraging efficient market competition and regulatory systems that are either deliberately anticompetitive or, more likely, simply indifferent to their competitive effects. But where it is the state itself that decides upon an anticompetitive end, the antitrust laws have not intervened, either because of worries about federal-state relations or (at the federal level) worries about the relationship between the judiciary and the administrative state. Thus, the state of California was free during the Great Depression to organize raisin-growing cooperatives that bought up and destroyed the majority of the raisin crop in order to create artificial scarcity, raising prices on food at a time when buyers could ill afford it. ${ }^{16}$ This was undeniably stupid economic policy, but it was government-set economic policy, and the Supreme Court concluded that the courts did not have the constitutional power to reverse it. ${ }^{17}$ That remains the rule: state

15 See Standard Oil Co. v. FTC, 340 U.S. 231, 248 (1951) ("The heart of our national economic policy long has been faith in the value of competition.”); Brown Shoe Co. v. United States, 370 U.S. 294, 320 (1962).

16 Parker v. Brown, 317 U.S. 341 (1943).

17 Id. at $350-52$. 
regulations that affect or even destroy competition are not antitrust violations. ${ }^{18}$ This is true even if those actions are venal - if they are the result of capture or bribery of the government decisionmakers by those who stand to benefit from their regulations. In City of Columbia v. Omni Outdoor Advertising, for example, the Court immunized city regulations that forbad construction of new billboards, even though the evidence established that those regulations were passed at the behest of the incumbent monopoly owner of existing billboards in the city in an effort to prevent new entry. ${ }^{19}$

States do not always act as brazenly as they did in Parker v. Brown, however. Sometimes governments will interfere with competition not by restricting it directly, but by setting up licensing schemes or rules that effectively delegate market control to private actors. For example, in FTC v. Ticor Title, the government challenged a state rule that allowed competitors to collectively agree on the rates they would charge for title insurance; the state then "adopted" those rates by default unless it affirmatively acted to veto or change the rates. ${ }^{20}$ Those

18 See 1 Philip Areeda \& Herbert Hovenkamp, Antitrust Law para. 200, at 148 ("antitrust's intervention into the political process is inappropriate once it is determined that the government itself rather than a private actor is the relevant decision maker."). Because this rule derives from concerns about federalism and state sovereignty, it does not necessarily apply to acts by municipalities. See Community Communications Co. v. City of Boulder, 455 U.S. 40, 50-52 (1982) (“Our precedents thus reveal that [a municipality's action] cannot be exempt from antitrust scrutiny unless it constitutes the actions of the State ... itself in its sovereign capacity, see Parker, or unless it constitutes municipal action in furtherance or implementation of clearly articulated and affirmatively expressed state policy ....") (other citations omitted). In the early 1980s, Congress passed a statute exempting municipalities and their employees from damages for antitrust violations, but the statute does not limit the availability of injunctive relief, and its passage confirms that municipalities' exemption is a statutory one, rather than one based on the federalism or constitutional concerns identified in Parker. See Local Government Antitrust Act, 15 U.S.C. $\S \S 34-35$.

19499 U.S. 365 (1991).

20 Federal Trade Comm'n v. Ticor Title Ins. Co., 504 U.S. 621 (1992); see also Southern Motor Rate Carriers Conf. v. United States, 471 U.S. 48 (1985); California Retail Liquor Dealers Ass'n v. Midcal Aluminum, Inc., 445 U.S. 97 (1980). 
quasi-state actions are subject to a more complex set of antitrust rules, one that seeks to distinguish between restraints of trade that are effectively government-controlled and those that are effectively private, shielded merely by a "gauzy cloak" of government blessing. ${ }^{21}$ Thus, government delegations of this sort are permissible only if the government clearly articulates its intent to displace market competition and actively supervises the activity of the private entities to which it has delegated control. ${ }^{22}$

A third set of cases involve purely private acts that occur in the shadow of a government regulatory regime. For example, government regulations often restrict entry into markets, sometimes expressly and sometimes by delaying that entry pending regulatory approval or raising its costs. Private actors can and do take advantage of these regulatory barriers to acquire or consolidate market power. Here too the antitrust laws have traditionally distinguished between limits on competition that result directly from the government's own acts - the inability of generic pharmaceutical competitors to enter the market without FDA approval, for example and private acts designed to take advantage of the regulatory regime to exacerbate monopoly power or market harm. But where the conduct is clearly private, antitrust law has historically been unwilling to cede ground to administrative agencies at either the state or federal level. The

21 Cal. Retail, 445 U.S. at 105-06. For skepticism as to whether this public-private distinction is plausible, see McGowan \& Lemley, supra note _, at 315-22, 356-57; cf. Einer R. Elhauge, The Scope of Antitrust Process, 104 Harv. L. Rev. 668, 669 (1991) (rejecting the public-private distinction, and attempting to replace it with an assessment of the disinterestedness of the government actors).

22 Ticor Title, 504 U.S. at 633 ("Actual state involvement, not deference to private pricefixing arrangements under the general auspices of state law, is the precondition for immunity from federal law."). 
Supreme Court made it clear early on that it did not look kindly on claims that a regulatory regime impliedly repealed the antitrust laws. ${ }^{23}$ As John Wiley observed in 1986:

The Supreme Court's rules for finding exemptions to antitrust policy testify to the dominance of Sherman Act policy: the Court disclaims its authority to create antitrust exemptions; ${ }^{24}$ is reluctant to imply them $;{ }^{25}$ and construes express exemptions narrowlyoften remarkably so. ${ }^{26}$

Government action may be exempt from antitrust scrutiny, but regulation traditionally has not meant a similar immunity for private action in regulated industries. Thus, in Silver v. New York Stock Exchange, the Court held that the Securities Exchange Act did not displace antitrust scrutiny over the NYSE, even though the antitrust issue - membership in the exchange was one subject to SEC rules. The Court said that "repeal of the antitrust laws is to be regarded as implied only if necessary to make the Securities Exchange Act work, and even then only to the minimum extent necessary."27

The traditional coexistence of regulated industries and antitrust appears to be changing, however. In a number of cases in the past decade the Supreme Court has either found implied repeal of the antitrust laws in the face of regulation or has held that antitrust cannot or need not govern anticompetitive conduct in industries in which regulatory agencies are active, even if those agencies are not directly supervising the anticompetitive conduct at issue in the case.

23 Union Labor Life Ins. Co. v. Pireno, 458 U.S. 119, 126 (1982); John S. Wiley, Jr., A Capture Theory of Antitrust Federalism, 99 Harv. L. Rev. 713, 713 n.1 (1986).

24 See National Soc'y of Professional Eng'rs v. United States, 435 U.S. 679, 692 (1978).

25 See National Gerimedical Hosp. \& Gerontology Center v. Blue Cross, 452 U.S. 378, 388-89 (1981).

26 Wiley, supra note _, at 713 n.1 (citing Group Life \& Health Ins. Co. v. Royal Drug Co., 440 U.S. 205 (1979)) (other citations converted to footnotes).

27 Silver v. New York Stock Exchange, 373 U.S. 341, 357 (1963). 
While the Court continues to recite the same legal standard, requiring a "plain repugnancy" between the antitrust and regulatory provisions, ${ }^{28}$ it is plain that the Court views antitrust as more repugnant than it has in the past. $^{29}$

In Verizon v. Trinko, ${ }^{30}$ for example, the Court considered an antitrust claim against an incumbent local exchange telephone provider (LEC), alleging that the LEC had refused to deal on nondiscriminatory terms with customers of newly-created competitive local exchange carriers (CLECs), denying them effective access to the LEC's monopoly facilities. The Court could not conclude that the Telecommunications Act preempted antitrust law in this area, because the Act itself said that it didn't. ${ }^{31}$ Nonetheless, the Court rejected the plaintiff's essential facilities antitrust claim, engaging in some revisionist history in saying that the Court had never endorsed such a claim before ${ }^{32}$ and suggesting that antitrust courts should tread lightly around markets that have "a regulatory structure designed to deter and remedy anti-competitive harm.",33

28 CreditSuisse Securities, LLC v. Billing, 127 S.Ct. 2383, 2390 (2007).

29 The Court's animosity to antitrust claims extends well beyond the issue of regulatory deference. It has been sixteen years since the Court has ruled for an antitrust plaintiff. See, e.g., Leegin Creative Leather Products, Inc. v. PSKS, Inc., 127 S.Ct. 2705 (1007) (abandoning per se rule against vertical minimum resale-price agreements); Bell Atlantic Corp. v. Twombly, 127 S.Ct. 1955 (2007) (heightening pleadings requirement for private antitrust claims). While we have some concerns about this general contraction of antitrust's scope, they are beyond the scope of this article; our point here is that antitrust law's substantive standards - whatever they may be - should continue to play a role in regulated industries.

30 Verizon Communications Inc. v. Law Offices of Curtis V. Trinko, LLP, 540 U.S. 398 (2004). For some reason, everyone calls the case "Trinko" even though the petitioner was Verizon, and we follow that convention here.

31110 Stat. 143, § 601(b)(1). See Trinko, 540 U.S. at 406.

32 Id. at 411. Contra Otter Tail Power Co. v. United States, 410 U.S. 366 (1973) (finding liability on an essential facilities theory, ironically in a regulated industries case). The Trinko Court did not cite or discuss Otter Tail. Cf. AT\&T Corp. v. Iowa Utilities Bd., 525 U.S. 366, 428 (1999) (Breyer, J., concurring) (describing essential facilities as "an antitrust doctrine that this Court has never adopted").

${ }^{33}$ Id. at 411. 
Commentators have differed over the meaning of Trinko. Verizon views the opinion as a categorical rejection of antitrust enforcement in regulated industries, ${ }^{34}$ but the Court in our opinion does not go that far. An alternative view of the opinion is as a rejection of the antitrust theory of essential facilities and unilateral refusals to deal, one applicable regardless of the industry context. It is true that the Court appears hostile to those claims. But the Court also spent a great deal of time discussing the regulatory structure of the market and how it made antitrust law unnecessary. ${ }^{35}$ Finally, some discern in Trinko a more flexible discretionary principle, in which judges should consider the relative institutional competencies of courts and regulators before intervening in regulated markets. ${ }^{36}$ Under this approach, courts should consider not only the existence of the regulatory agency, but its empowerment and commitment to addressing competition-related concerns. ${ }^{37}$

34 E.g., John Thorne, A Categorical Rule Limiting Section 2 of the Sherman Act: Verizon v. Trinko, 72 U. Chi. L. Rev. 289 (2005) (viewing case as a categorical rejection of refusal-to-deal claims in regulated industries).

35 Trinko, 540 U.S. at 411-16.

36 See, e.g., Weiser, supra note 1, at 10 (suggesting that "the extent of antitrust restraint should vary depending on whether the regulatory regime is reasonably effective at addressing the relevant anticompetitive conduct"); Herbert Hovenkamp, Antitrust and the Regulatory Enterprise, 2004 Colum. Bus. L. Rev. 335; cf. Andrew I. Gavil, Exclusionary Distribution Strategies by Dominant Firms: Striking a Better Balance, 72 Antitrust L.J. 3, 42 (2004) ("At its core, [Trinko] suggests little more than that courts should be reluctant to scrutinize pure, unilateral refusals to assist rivals by dominant firms in industries subject to extensive, competition-focused regulation, particularly if the government scheme regulates access to the dominant firm's facilities.'); C. Scott Hemphill, Paying for Delay: Pharmaceutical Patent Settlements as a Regulatory Design Problem, 81 N.Y.U.L. Rev. 1553, 1557 (2006) ("Identifying the impact of an industry-specific regulatory regime in a particular context requires careful, sustained attention to the principal features of the relevant regulatory structure.").

37 Phil Weiser, for example, has advocated a hands-on approach for antitrust courts in communications cases, based on what he sees as the FCC's "deliberate under-enforcement strategy" in the current deregulatory era. Weiser, supra note 1; see also Hovenkamp, supra note , at 352; Covad Communications Co. v. BellSouth Corp., 374 F.3d 1044 (11th Cir. 2004) (holding that predatory price squeeze claim survives Trinko, when the antitrust claim "depends upon [a specific regulatory decision] only in a circular sense") ; Z-Tel v. SBC, cite (limiting 
Regardless how one reads the opinion, however, the Court seems inclined to think that the existence of a regulated industry makes antitrust law less important. Its reasoning is twofold. First, if an industry regulator is evaluating competition issues, "the additional benefit to competition provided by antitrust enforcement will tend to be small,, 38 presumably because the regulators can serve that role. ${ }^{39}$ Second, the Court emphasized the risk of mistaken findings of antitrust liability, describing them as "especially costly, because they chill the very conduct the antitrust laws were designed to protect." ${ }^{, 40}$ Relevant to both points, the Court suggested that specialist regulators were likely to be better at evaluating competition economics than a generalist antitrust court. ${ }^{41}$

This theme - the comparative advantage of regulators over antitrust courts in promoting competition - shows up in other Court opinions as well. In CreditSuisse Securities v. Billing, ${ }^{42}$ for instance, which involved allegations of clearly anticompetitive collusion by underwriters, the Court nonetheless rejected application of the antitrust laws because it found that the Securities

Trinko to cases involving novel antitrust claims - even in regulated industries - but finding traditional antitrust claims viable even in regulated markets: "As a legal matter, Trinko instructs us that antitrust liability is live and well in the context of regulated industries."); Stand Energy Corp. v. Columbia Gas Transmission Corp., 373 F. Supp. 631, 641 (S.D.W.Va. 2005) (relying upon Otter Tail to allow essential facilities claim in regulated industry, when "FERC's authority to remedy anti-competitive behavior is decidedly less than the regulatory authority in Trinko"). In re Remeron (important, because it's an orange book/patent case); linkLine Communications, Inc. v. SBC California, Inc., 503 F.3d 876, 882 (9th Cir. 2007) ("Importantly, the Court did not say that the existence of a regulatory scheme was a per se bar to judicial enforcement of the antitrust laws, only that 'the existence of a regulatory structure' is '[o]ne factor of particular importance."”) (quoting Trinko, 540 U.S. at 412).

38 Trinko, 540 U.S. at 412.

39 Even where regulation doesn't serve a competition-protecting function, the Court was hesitant to endorse antitrust scrutiny, pointing to its "sometimes considerable disadvantages." Id.

40 Id. at 414 .

41 Id.

$42 \quad 127$ S.Ct. 2383. 
and Exchange Commission (SEC) was heavily involved in regulating what underwriters could do, and while the SEC too forbad much of the conduct complained of, it would be too hard for antitrust courts to prevent collusion without deterring conduct the SEC had chosen to permit. CreditSuisse, like Trinko, concludes that "any enforcement-related need for an antitrust lawsuit is unusually small" because the SEC can step in to prevent collusion. ${ }^{43}$ The Court also emphasized the limitations of antitrust's "nonexpert judges and nonexpert juries" and the "unusually high risk that different courts will evaluate similar factual circumstances differently., ${ }^{24}$ And like Trinko, it emphasized the risk of false positives while not discussing the risk of false negatives, worrying that "antitrust courts are likely to make unusually serious mistakes in this respect." CreditSuisse, like Trinko, is capable of various readings. The actual holding of the case is quite limited, and the Court's reliance on the strict legal standard from prior cases suggests that the case might stand for no more than the application of that standard to a precise set of facts. But the Court's long discussion of the comparative advantages of regulation over antitrust enforcement, a discussion that never mentions Trinko but echoes its arguments almost completely, suggests that something broader is going on here: a move toward antitrust deference in the face of regulation.

In short, antitrust courts seem increasingly willing to permit private anticompetitive acts that occur in the shadow of regulation, relying on regulators to perform the traditional antitrust function of protecting competition and sometimes turning a blind eye even when regulators cannot or do not do so.

$\begin{array}{ll}43 & \text { Id. at } 2396 . \\ 44 & I d . \text { at } 2395 . \\ & \\ 45 & \text { Id. at } 2396 .\end{array}$ 


\section{The Relative Efficiency of Antitrust and Regulation}

The growing antitrust deference to regulation is cause for concern. Both antitrust and regulation are economic responses to market failures. ${ }^{46}$ Implemented correctly, both are designed to serve the ends of economic efficiency. ${ }^{47}$ It is therefore reasonable to judge the relative efficacy of antitrust and regulation by economic criteria. And judged by those criteria, virtually all economists would agree that antitrust-overseen market competition is superior to industry regulation. In particular, none of the arguments the Court has offered as a reason to prefer regulation to antitrust withstand scrutiny.

Relative expertise. It is true, as the Court emphasized in Trinko and CreditSuisse, that antitrust courts are generalist courts, while regulatory agencies tend to specialize in a particular industry and its problems. That specialization should, all other things being equal, mean that expert regulators will do a better job than judges or juries of reaching the right result. But other things are far from being equal. Antitrust courts have two significant advantages over regulatory agencies when it comes to promoting competition.

First, antitrust courts are trying to promote economic efficiency, while regulators often aren't. For decades, efficiency has served as the sole criterion on which to judge antitrust rules. And courts have had over a century in which to hone those rules to achieve that end. Without question, courts have made mistakes in the past. But there is a strong consensus among antitrust scholars that the wave of cases in the last 30 years has largely moved antitrust in the right

46 See, e.g., Hovenkamp, supra note _, at 336-37 (noting complementarity of antitrust and regulation); Stephen Breyer, Regulation and Its Reform 156-57 (1982).

47 Of course, antitrust and regulation take different approaches to achieving their common goal, but both ultimately aim to maximize efficiency in markets. See Breyer, supra note _, at 156-57 ("The antitrust laws seek to create or maintain the conditions of a competitive marketplace rather than replicate the results of competition or correct for the defects of competitive markets."). 
direction, eliminating any significant risk that antitrust enforcement will do more harm than good. ${ }^{48}$ Scholars may fight over whether a Chicago School or a post-Chicago School approach will achieve the right result in specific cases, ${ }^{49}$ but for the most part they are tinkering at the margins: the law and the scholarship have converged with respect to both the proper goals of antitrust and the general rules that will achieve those goals.

Regulation, by contrast, is frequently not even intended to achieve economic efficiency through competition. Occasionally that is because of a legislative judgment that competition is impossible, though the number of industries thought to be natural monopolies for which markets won't work has shrunk dramatically in the past four decades. ${ }^{50}$ Industry regulation that excludes entry in order to promote a natural monopoly, as telephone regulation did before 1984, is not likely to achieve a competitive outcome.

More often, the goals of the legislators who establish regulatory agencies, or the goals of the regulators who run those agencies, are to achieve something other than competition. Indeed,

48 See Areeda \& Hovenkamp, supra note _, at 9110 a ("Today it seems clear that the general goal of the antitrust laws is to promote 'competition' as the economist understands that term. Thus we say that the principal objective of antitrust policy is to maximize consumer welfare by encouraging firms to behave competitively while yet permitting them to take advantage of every available economy that comes from internal or jointly created production efficiencies, or from innovation producing new processes or new or improved products."); Michael S. Jacobs, An Essay on the Normative Foundations of Antitrust Economics, 74 N.C. L. Rev. 219, 220-22 (1995) (noting increasing consensus between Chicago and post-Chicago views on antitrust's appropriate goals); $c f$. William E. Kovacic, The Intellectual DNA of Modern U.S. Competition Law for Dominant Firm Conduct: The Chicago/Harvard Double Helix, 2007 Colum. Bus. L. Rev. 1 (2007) (noting influence of both "Harvard School" and "Chicago School" in narrowing and focusing the scope of antitrust claims in recent decades); Richard A. Posner, The Chicago School of Antitrust Analysis, 126 U. Penn. L. Rev. 925 (1979) (observing increased convergence of scholars' views on the appropriate role of antitrust laws).

49 See Areeda \& Hovenkamp, supra note _, at $1112 \mathrm{~d}$ (summarizing remaining doctrinal and methodological differences between the "Chicago School" and the "Harvard School").

50 See Herbert Hovenkamp, The Antitrust Enterprise: Principle and Execution 228 (2006) (noting the success of deregulation in recent decades in industries once viewed as natural monopolies that required regulatory oversight). 
many regulations are aimed precisely at eliminating competition, as was the governmentsponsored raisin cartel in Parker v. Brown ${ }^{51}$ or any of its modern descendent crop-support programs administered by the Department of Agriculture. It should be obvious that regulations intended to reduce competition will not promote it. But even if the regulation is not directly inimical to competition, competition is frequently irrelevant to, or at best a minor consideration in, a regulator's agenda. Regulators may care about the safety and efficacy of a drug, for example, and only incidentally about whether there is competition in the sale of that drug. They may seek to reduce traffic deaths or air pollution by mandating technology, regardless of the effect that mandate has on the price manufacturers can charge or the number of products they sell. These are laudable goals, to be sure, but they are not competition-related goals. An agency tasked with achieving these goals is likely to ignore threats to competition from the industry it regulates so long as those threats do not compromise its core mission. Thus, the state and local governments that enacted the privately-drafted National Fire Protection Code at issue in Allied Tube into law were interested in stopping fires; doubtless they thought little if at all about the competitive effects of the code, even though it turned out that the code was drafted by interested private parties with the purpose of impeding competition rather than promoting fire safety. ${ }^{52}$

Even those agencies whose mission expressly involves consideration of competition issues will not necessarily make it their first among potentially conflicting priorities. The SEC, for example, which as Justice Breyer pointed out is dedicated to improving market information and expressly considers competition among other issues in setting regulation, ${ }^{53}$ is first and foremost an investor-protection and information-disclosure agency, not an agency that

51 Parker v. Brown, 317 U.S. 341 (1943).

52 Allied Tube \& Conduit Corp. v. Indian Head, Inc., 486 U.S. 492 (1988).

53 CreditSuisse, 127 S.Ct. at 2396 (citing 15 U.S.C. $\S \S 77 b(b), 78 w(a)(2)$ ). 
investigates and weeds out cartels or other anticompetitive practices. It is unlikely to devote much in the way of time or resources to such issues, because even if it is tasked to consider such issues they do not reflect the agency's primary purpose. Similarly, even an agency like the Federal Communications Commission that is directly focused on competitive conditions in a particular market may naturally pay attention primarily to that market, and give less if any attention to the effect its rules might have on competition in adjacent markets or competition from unanticipated new businesses. This arguably explains the FCC's willingness to largely ignore the effects of its decisions on the Internet, for example: it is telecommunications, not the Internet, that the $\mathrm{FCC}$ is tasked to regulate.

Agencies that view competition as secondary, or view it through the lens of a particular industry's characteristics and interests, are less likely to create and enforce rules that optimally encourage competition. ${ }^{54}$ At a bare minimum, therefore, the industry-specific expertise of an agency must be balanced against the competition-specific expertise of the specialist antitrust agencies: the Federal Trade Commission (FTC) and the Department of Justice Antitrust Division.

The problem with agencies is much greater than just their questionable mandate to promote competition, however. Agencies are famously subject to "capture" by the industries they are supposed to regulate. ${ }^{55}$ That capture can take many different forms. Sometimes

54 See 1A Areeda \& Hovenkamp, supra note__, at 283 ("agencies and antitrust courts have often had different attitudes toward the importance of competition in the regulated sector. Often the antitrust authorities are more skeptical than regulators about industry claims of efficiency or the social benefits of restraints on competition.").

55 Among the considerable literature on agency capture, see, e.g., Stephen G. Breyer, Regulation and Its Reform (1994); 1A Areeda \& Hovenkamp, supra note _ , para. 241b2; James Buchanan \& Gordon Tullock, The Calculus of Consent (1962); Daniel A. Farber \& Philip P. Frickey, Law and Public Choice, a Critical Introduction (1991); George J. Stigler, The Theory of 
regulators or legislators are captured in the most venal sense - they are bribed or otherwise given personal benefits in exchange for voting a particular way. This seems to have been the case in Omni Outdoor Advertising, for example. Regulators who accept bribes (or politicians who accept campaign contributions in exchange for a particular vote) are not acting in the public interest but in their private interest, a private interest that necessarily aligns with the industry participant doing the bribing. Even a regulator who would never accept bribes may still seek to maximize, not the public interest, but his own power or the power and interests of his agency, a fact that industry can often use to its advantage.

Capture need not be so brazen, however. Even honest regulators and legislators can be captured through the mechanism of public choice theory. ${ }^{56}$ A legislator that tries to maximize her constituents' expressed preferences may still end up supporting legislation that benefits private firms at the expense of the public interest, because the private firms will frequently have a concentrated interest - and therefore show up to lobby on a particular issue - while the public is hard to organize even around issues that may affect a great many of them diffusely.

Regulators are subject to the same effect. A notice and comment rulemaking is likely to produce more comments from people with a concentrated interest in the outcome, and fewer comments from those with a more diffuse interest. Thus, regulators who try in good faith to determine what the public thinks of a particular regulation may still end up with a skewed view of the pros and cons. This may be particularly likely with competition issues. While the public as a whole has a strong interest in unfettered competition, any individual member of the public is unlikely to be affected much by a particular regulatory decision. And particularly where the industry as a

Economic Regulation, 2 Bell J. Econ. \& Mgmt. Sci. 3 (1971); Richard A. Posner, Theories of Economic Regulation, 5 Bell J. Econ. \& Mgmt. Sci. 335 (1974).

56 Mancur Olson, The Logic of Collective Action (1965). 
whole colludes to seek regulatory intervention that benefits them, as in Ticor Title, there are unlikely to be competitors who can stand as proxy for the interests of the public.

Finally, even legislators and regulators aware of the existence of public choice problems and determined to do the right thing are still susceptible to forms of what we might call "soft" capture. Acquiring accurate information about market conditions is often very difficult, for example. Companies with a vested interest in the outcome can hire lobbyists that provide information helpful to their side, and a regulator who cannot get information except from those lobbyists may have little choice but to accept that information as true. Even if there are competing sources of information, interested parties can and do hire as lobbyists former employees, colleagues, or friends of the regulator, and it is natural human instinct to trust those people more than strangers. And regulators tend to come from the industries they regulate, which may mean that they start out seeing things from the industry's perspective.

Judges, by contrast, are much less subject either to having their purpose diverted or to capture. While some have tried to argue that judges face some of the same interest group constraints as legislators and administrative agencies, ${ }^{57}$ the fact is that antitrust courts are trying to achieve the goal of economic efficiency, they are doing it in industries in which they have no direct financial interest, they cannot act to benefit their "agency" in rendering a decision, and the structure of the litigation process helps ensure to the extent possible that both sides are presented in a relatively balanced way. Courts aren't perfect, of course. But all advantages are comparative, and the fact that antitrust courts are trying to promote competition rather than to achieve some other end (whether legislated or self-motivated) provides a powerful counterweight to the industry expertise of administrative agencies. It is important to keep in mind, as Areeda

57 See Einer Elhauge, Does Interest Group Theory Justify More Intrusive Judicial Review?, 101 Yale L.J. 31 (1991). 
and Hovenkamp summarize, that "it often turn[s] out that the principal beneficiaries of industry regulation were the regulated firms themselves, which were shielded from competition and guaranteed profit margins." ${ }^{\text {"58 }}$ Courts should not assume that regulation will lead to competition merely because regulators know more than courts about the industries they regulate.

False positive and false negatives. A second concern expressed by the Court is that the risk of false positives - courts finding antitrust violations when in fact there are none - far outweighs the risk of false negatives, and that this is particularly true in regulated industries. That concern may once have had some force, but it no longer does.

To begin, it is worth noting the recent history of antitrust decisions - a history that is, almost without exception, one that makes it harder over time for antitrust plaintiffs to win cases. Judge Easterbrook could speak in 1984 of the asymmetry between false positive and false negatives, ${ }^{59}$ but the antitrust law he was talking about simply doesn't exist anymore. Courts in the last three decades have dismantled every per se rule applied to vertical conduct, ${ }^{60}$ limited the per se rule in horizontal conspiracies in a variety of ways, ${ }^{61}$ made it harder for plaintiffs to infer

58 1A Areeda \& Hovenkamp, supra note _, para 241b2, at 293.

59 Frank H. Easterbrook, The Limits of Antitrust, 63 TEX. L. REV. 1 (1984).

60 Leegin Creative Leather Products, Inc. v. PSKS, Inc., 127 S. Ct. 2705 (2007); State Oil Co. v. Khan, 522 U.S. 3 (1997); Business Electronics Corp. v. Sharp Electronics Corp., 485 U.S. 717 (1988); Illinois Tool Works, Inc. v. Independent Ink, Inc., 547 U.S. 28 (2006); NYNEX Corp. v. Discon, Inc., 525 U.S. 128 (1998).

61 Texaco, Inc. v. Dagher, 547 U.S. 1 (2006); National Collegiate Athletic Ass'n v. Board of Regents, 468 U.S. 85 (1984); Broadcast Music, Inc. v. Columbia Broadcast Sys., Inc., 441 U.S. 1 (1979); Northwest Wholesale Stationers, Inc. v. Pacific Stationery \& Printing Co., 472 U.S. 284 (1985). 
conspiracies, ${ }^{62}$ all but eliminated predatory pricing claims, ${ }^{63}$ and substantially restricted the role of monopolization cases. ${ }^{64}$ Win rates for antitrust plaintiffs in at least one industry hover below $15 \%,{ }^{65}$ and court rules make it harder and harder for antitrust plaintiffs to show standing to sue to enforce the laws that remain. ${ }^{66}$

We have no doubt that antitrust at one time was skewed towards overenforcement, but today if there is any bias it is in the opposite direction. The Supreme Court has now decided 16 antitrust cases in a row in favor of defendants, ${ }^{67}$ and the $A T \& T$ case seems poised to be the $17^{\text {th }}$. It has been 16 years since an antitrust plaintiff won in the Supreme Court. Courts are willing to permit obvious cartels and market division schemes to survive antitrust scrutiny, sometimes

62 Bell Atlantic Corp. v. Twombly, 127 S. Ct. 1955 (2007); Matsushita Elec. Indus. Co., Ltd. v. Zenith Radio Corp., 475 U.S. 574 (1986); Monsanto Co. v. Spray-Rite Service Corp., 465 U.S. 752 (1984).

63 Brooke Group Ltd. v. Brown \& Williamson Tobacco Corp., 509 U.S. 209 (1993) (requiring proof of below-cost pricing and probability of recoupment in predatory pricing claims); Matsushita Elec. Indus. Co. v. Zenith Radio Corp., 475 U.S. 574 (1986) (enhancing pleading requirements in predatory pricing cases); Weyerhaeuser Co. v. Ross-Simmons Hardwood Lumber Co., 127 S. Ct. 1069 (2007) (holding that stringent standard for predatory pricing also applies to predatory bidding claims).

64 Verizon Communications Inc. v. Law Offices of Curtis V. Trinko, LLP, 540 U.S. 398 (2004).

65 See Peter J. Hammer \& William M. Sage, Antitrust, Health Care Quality, and the Courts, 102 Colum. L. Rev. 545, 575 (2002) (study concluding that plaintiffs win only fourteen percent of antitrust cases in the health care industry). While the health care industry may not be representative, it supports a general consensus that plaintiffs rarely win antitrust suits. But see Daniel A. Crane, Rules Versus Standards in Antitrust Adjudication, 64 Wash. \& Lee L. Rev. 49, 65 (2008) (contending that rule of reason has become "reinvigorated" in recent years, leading to more wins for plaintiffs).

66 Atlantic Richfield Co. v. USA Petroleum Co., 495 U.S. 328 (1990) (holding that antitrust plaintiffs must prove "antitrust injury" - i.e., that their injury resulted from harm to the competitive process); Brunswick Corp. v. Pueblo Bowl-O-Mat, Inc., 429 U.S. 477, 489 (1977) ("Plaintiffs must prove antitrust injury, which is to say injury of the type the antitrust laws were intended to prevent and that flows from that which makes defendants' acts unlawful.").

67 See William Polasky, Reinvigorating Antitrust Enforcement in the United States: A Proposal, 22 Antitrust 85, 85 (2008) (noting lax antitrust enforcement and pro-defendant bent of the Roberts Court, and listing the cases). 
going so far as to call them per se legal,$^{68}$ and seem unwilling to restrict anticompetitive behavior by patentees. ${ }^{69}$ The Antitrust Division, tasked with enforcing the antitrust laws, permits mergers to monopoly ${ }^{70}$ and seems to spend as much time arguing in favor of antitrust defendants as it does suing them. ${ }^{71}$ We don't intend to suggest that antitrust law is dead; the agencies continue to prosecute cartels, and private parties continue to file antitrust cases. But for the Supreme Court to say that antitrust is too expansive - that antitrust courts are more likely to wrongly find an

68 In re Tamoxifen Antitrust Litigation, 466 F.3d 187 (2d Cir. 2006) (concluding that "reversepayment" settlement - in which patent plaintiff pays challenger to drop its validity challenge and stay out of the market - did not violate the antitrust laws); Schering-Plough v. Fed. Trade Comm'n, 402 F.3d 1056, 1076 (11th Cir. 2005) (same); Valley Drug Co. v. Geneva Pharm., Inc., 344 F.3d 1294 (11th Cir. 2003) (same); In re Ciprofloxacin Hydrochloride, 363 F. Supp. 2d 514 (E.D.N.Y. 2005) (same). But see In re Cardizem CD Antitrust Litig., 332 F.3d 896, 908 (6th Cir. 2003) (finding reverse payment a per se antitrust violation).

69 See Rambus, Inc. v. Federal Trade Commission, 522 F.3d 456 (D.C. Cir. 2008); cf. Rambus, Inc. v. Infineon Technologies AG, 318 F.3d 1081 (Fed. Cir. 2003).

70 See Press Release, U.S. Dep't of Justice, Statement of the Dep't of Justice on its Decision to Close its Investigation of XM Satellite Radio Holdings Inc. 's Merger with Sirius Satellite Radio Inc. (March 24, 2008) (explaining decision not to challenge merger of the only two satellite radio firms in the United States), at http://www.usdoj.gov/opa/pr/2008/March/08_at_226.html; see also Jonathan B. Baker \& Carl Shapiro, Detecting and Reversing the Decline in Horizontal Merger Enforcement, 22 Antitrust 29, 32 \& n.17 (2008) (criticizing decision for giving insufficient weight to anticompetitive concerns raised by merger).

71 Indeed, the DOJ went so far as to file a brief urging the Supreme Court to reject a petition for certiorari filed by its sister agency, the Federal Trade Commission. See Brief for the United States as Amicus Curiae, Federal Trade Comm'n v. Schering-Plough Corp., 126 S. Ct. 2929 (2005), 2006 WL 1358441. More generally, the Antitrust Division has filed pro-defendant briefs in all of the major antitrust cases before the Supreme Court in the past five years. See Brief for the United States as Amicus Curiae, Leegin Creative Leather Prods., Inc. v. PSKS Inc., 127 S. Ct. 2705, 2007 WL 173650 (filed Jan. 22, 2007); Brief of the United States as Amicus Curiae Supporting Vacatur, Credit Suisse Securities (USA) LLC v. Billing, 127 S. Ct. 2803, 2007 WL 173649 (filed Jan. 22, 2007); Brief for the United States as Amicus Curiae Supporting Petitioners, Bell Atlantic Corp. v. Twombly, 127 S. Ct. 1955, 2006 WL 2482696 (filed Aug. 25, 2006); Brief of the United States as Amicus Curiae Supporting Petitioner, Weyerhaeuser Co. v. Ross-Simmons Hardwood Lumber Co., 127 S. Ct. 1069, 2006 WL 2452373 (filed Aug. 24, 2006); Illinois Tool Works Inc. v. Independent Ink, Inc., 547 U.S. 28, 2005 WL 1864093 (filed Aug 4, 2005). 
antitrust violation than to wrongly let one go unpunished - flies in the face of the realities of modern antitrust.

The question then becomes whether there is something about the regulatory environment that causes false positives to be particularly likely. Both Trinko and CreditSuisse suggest that the answer is yes. CreditSuisse suggests that because the antitrust claims at issue in that case, while covering conduct the SEC had itself forbidden, was hard to distinguish from other conduct the SEC had chosen to allow, there was "no practical way to confine antitrust suits so that they challenge only activity of the kind the investors seek to target," suggesting that "antitrust courts are likely to make unusually serious mistakes in this respect."72 Trinko suggests that the conduct at issue there was "the very conduct the antitrust laws are designed to protect," so that mistaken condemnations "are especially costly" and likely to chill legitimate business behavior. ${ }^{73}$

In fact, however, we believe there is less, not more, of a worry about false positives in the presence of regulation, because regulators can easily protect particular types of conduct from antitrust scrutiny by the simple expedient of adopting or requiring it. If the SEC expressly requires certain collaboration or information disclosure by underwriters, for example, antitrust will not condemn that conduct even if it would find that collusion unlawful in an unregulated industry. It is true that antitrust may have a harder task in industries in which a regulatory agency has blessed certain conduct and therefore put it beyond the reach of antitrust law, but the hard task would seem to be effective enforcement, not preventing too much enforcement. So long as antitrust scrutiny is properly focused on private activity rather than regulatory decisions, the presence of regulation is likely to further circumscribe antitrust, not to lead to more false positives.

72 CreditSuisse, 127 S.Ct. at 2395-96.

73 Trinko, 540 U.S. at 414. 
Duplication of effort. Finally, the Court suggests in each of these cases that the value of antitrust enforcement is reduced because the administrative agency can perform the same competition-protecting function. If the premise is true, this argument has some force: the incremental value of antitrust enforcement is less if a regulator is already serving the enforcement function. In practice, however, we are skeptical that this will often be the case, or that it will justify abdication of judicial responsibility for antitrust enforcement.

To begin, we note that all of the problems we detailed above make it unlikely that very many administrative agencies will in fact serve as effective guardians of the competition function. ${ }^{74}$ Agencies that do not see promoting competition as a core part of their mission, or agencies that have been captured, are unlikely to get competition policy right. ${ }^{75}$ Further, even agencies that are willing to take competition into account rarely provide effective mechanisms to enforce competition policy or deter antitrust violations. An agency that stops certain conduct after it begins does not sufficiently deter antitrust violations; an agency that imposes modest fines but lacks the power to stop the conduct at all will be even less effective. And even if there is an effective remedy on the books, agencies are unlikely to have the interest and expertise in antitrust necessary to detect and enforce violations.

"Unlikely" is not "never," of course; there will be situations in which regulatory agencies can play an effective antitrust role in policing purely private conduct, and in those circumstances

74 See 1A Areeda \& Hovenkamp, supra note _, at 274-75 (arguing that antitrust should apply where "authorized oversight is incomplete or lacking entirely," and that "oversight [is] nearly always incomplete").

75 The Trinko Court is sensitive to the first problem, though not the second. It finds antitrust inappropriate if there is "a regulatory structure designed to deter and remedy anticompetitive harm," but it at least willing to apply antitrust if there is no such structure. Trinko, 540 U.S. at 412. 
the Court's argument that antitrust law is less important is fair. It is worth noting, however, that that argument has not carried the day in any other area of antitrust law. Federal antitrust law does not preempt state antitrust enforcement, even though states may have different and even occasionally conflicting rules governing remedies and even though the resulting remedies may be cumulative. ${ }^{76}$ U.S. antitrust law reaches across national boundaries to stop purely foreign conduct that has an effect on U.S. commerce, ${ }^{77}$ even though foreign nations also have antitrust laws and the overlap between them means that mergers and other conduct allowed in the U.S. may nonetheless be banned by foreign antitrust agencies. ${ }^{78}$ Federal and state antitrust enforcement co-exists with private rights of action under both state and federal antitrust laws,

76 Areeda \& Hovenkamp, supra note _, at 9216 p. 345 (“federal and state policy often overlap and address precisely the same practices, often with inconsistent results"); id. ๆף 2411-2419 (discussing inconsistencies between state and federal law); see California v. ARC Am. Corp., 490 U.S. 93 (1989) (holding that federal law did not preempt state antitrust laws allowing indirect purchasers to sue for damages).

77 United States v. Nippon Paper Indus. Co., 109 F.3d 1 (1st Cir. 1997) ("Section One of the Sherman Act applies to wholly foreign conduct which has an intended and substantial effect on the United States"); $c f$. F. Hoffman-LaRoche Ltd. v. Empagran S.A., 542 U.S. 155 (2004) (clarifying that such antitrust suits can reach only behavior that causes domestic injury, and cannot address conduct that causes independent foreign harm).

78 In 2001, for example, the European Community blocked a merger between General Electric and Honeywell that United States antitrust authorities had allowed, raising the ire of both antitrust authorities and the business community in the U.S. See Commission Decision 2004/134, Case COMP/M.2220, General Electric/Honeywell, 2004 O.J. (L 48) 1, at $\mathrm{http} / /$ ec.europa.eu/comm/competition/mergers/cases/decisions/m2220_en.pdf; see also Editorial, Europe to GE: Go Home, Wall St. J., June 15, 2001, at A14 ("In the Honeywell case, novel antitrust theories have been dreamed up simply because it would be unthinkable to let a large U.S. company go about its business unmolested."); Remarks of Deborah Platt Majoras, Deputy Assistant Attorney General, Antitrust Division, Before the Antitrust Law Section, State Bar of Georgia, Nov. 29, 2001, at http://www.usdoj.gov/atr/public/speeches/9893.htm\#N_2_; see generally Henry C. Thumann, Multijurisdictional Regulation of Monopoly in a Global Market, 2008 Wisc. L. Rev. 261, 262-63 (noting that "like the United States," other countries "have reached out and will continue to reach out to regulate conduct that directly lessens competition within their markets, regardless of where the triggering conduct occurs"). 
even though some have argued that the result is cumulative overdeterrence. ${ }^{79}$ And Antitrust Division review of certain mergers under Hart-Scott-Rodino ${ }^{80}$ coexists with the review of other specialty agencies. The Department of Transportation must sign off on airline mergers, and the FCC on telecommunications mergers, ${ }^{81}$ for example, even though the Antitrust Division and the FTC respectively have concurrent jurisdiction over those mergers. In short, antitrust law does not generally worry about the effects of overlapping enforcement, except when it comes to challenges to the behavior of regulated firms.

79 See, e.g., Jonathan T. Tomlin \& Dale J. Giali, Federalism and the Indirect Purchaser Mess, 11 George Mason L. Rev. 157, (2002) (contending that states' recognition of antitrust claims by indirect purchasers "could lead to inconsistent determinations and potentially duplicative damages, $\ldots$ the erosion of the effectiveness of antitrust law, ... arbitrary penalties and deterrence and a likelihood of overdeterrence"); Bruce H. Kobayashi, Antitrust, Agency, and Amnesty: An Economic Analysis of the Criminal Enforcement of the Antitrust Laws Against Corporations, 69 Geo. Wash. L. Rev. 715, 732-33 (2001) (noting risks of overdeterrence); $c f$. Michael K. Block \& Joseph Gregory Sidak, The Cost of Antitrust Deterrence: Why Not Hang a Price Fixer Now and Then?, 68 Geo. L.J. 1131, (1980) (contending that because of error risks, high antitrust sanctions may over-deter and result in suboptimal competition). It is far from clear that this overdeterrence concern is warranted in the modern world, however. See Robert H. Lande, Benefits from Private Antitrust Enforcement: An Analysis of Forty Cases, 42 U.S.F.L. Rev. 879, 907 (2008) (noting that criminal antitrust conduct "occurs far too frequently and is almost certainly significantly underdeterred - even factoring in the effects of the present system of private litigation"); Robert H. Lande, Why Antitrust Damage Levels Should Be Raised, 16 Loyola Consumer L. Rev. 329, 329 (2004) (contending that, "if the current antitrust damage levels are examined carefully, they do not even total treble damages, and overall are not high enough to deter antitrust violations optimally").

80 Hart-Scott-Rodino Antitrust Improvements Act of 1976, 15 U.S.C. $§ 18(a)$.

81 Indeed, because the agencies have different mandates, their merger approval is often subject to different conditions. Compare, e.g., United States v. AT\&T Corp., 65 Fed. Reg. 38,583 (DOJ June 21, 2000), at gov/atr/cases/f4800/4841.pdf (D.D.C. 2000) (consent decree approving merger subject to divestiture of certain interests of acquired party), with In re Applications for Consent to the Transfer of Control of Licenses and Section 214 Authorizations from MediaOne Group, Inc. to AT\&T Corp., Memorandum and Order, 15 F.C.C.R. 9816 (2000), at http://www.fcc.gov/bureaus/cable/orders/2000/fcc00202.doc (approving merger subject not only to DOJ consent decree regarding divestitures, but also to additional divestiture requirements and a commitment to provide nondiscriminatory access to network by unaffiliated internet service providers). 
Our goal in this section is not to argue that regulation never works, much less that antitrust should habitually second-guess decisions made by regulators. Our point is more limited. We worry that the recent trend toward antitrust deference has increasingly blurred the line between deference to regulatory action and deference to regulatory inaction. Such a trend, if it continued, could lead to complete antitrust immunity in regulated markets. This mutant form of antitrust deference - presumably based on the assumption that regulation is a more efficient way of preventing private anticompetitive conduct than antitrust enforcement - would be fundamentally misguided. Economics counsels against trusting regulators to look for, find, and deter anticompetitive conduct by private actors. It therefore counsels against a broad view of antitrust deference, and in favor of the conflicts-based approach that has long preserved the balance between antitrust laws and industry regulation.

\section{III.An Analytical Framework}

So far, we have shown why antitrust law has a continuing role to play in regulated industries. At the same time, we recognize that for regulation to be effective, regulators must have the power to fulfill their statutory mandate without constant oversight from antitrust courts. In this section, we suggest some principles for deciding when antitrust law should apply to behavior in regulated industries, and when courts should defer to regulators.

First, we believe antitrust courts are correct to defer to regulatory decisions themselves. If a regulator sets the price a company must charge, or sets entry conditions that prevent competition that might otherwise have existed, the result is anticompetitive, but the harm to competition results directly from decisions made by regulators who have the specific jurisdiction 
over the matter. ${ }^{82}$ Antitrust law does not trump other laws, but must coexist with them. If the law gives regulators control over a particular decision, antitrust law should not second-guess that decision. ${ }^{83}$ Indeed, paradigmatic cases of such state action don't involve private exclusionary behavior at all; it is the regulator, not the party being regulated, that creates whatever competitive harm exists.

Second, regulatory "gaming" that involves efforts to capture regulators or persuade them to limit competition will generally not be actionable so long as the effort to persuade regulators to one's viewpoint is a genuine one and so long as the anticompetitive effects result from the actions of the regulator so persuaded and not from the petitioning effort itself. Deference in this situation follows from the Noerr-Pennington doctrine and the First Amendment interests involved, but it also reflects the fact that private behavior that persuades a regulator to limit competition is not really private regulatory gaming at all, but ultimately public action, albeit public action encouraged by an interested private party.

In these petitioning/capture cases, however, deference should not be as absolute as it is in the pure state action cases. There are two circumstances in which private petitioning to obtain anticompetitive government action can run afoul of the antitrust laws. First, the government must in fact be the relevant actor. A government that reflexively blesses whatever prices are set by a private cartel is not in fact exercising its regulatory authority at all. Only if the government

82 See I Areeda \& Hovenkamp, supra note__, at 9202 p. 166 (“Once a court recognizes the official action as authorized under a valid statute, the antitrust court must recognize that any harm to competition results from government decision rather than from the private action that may have induced official action.").

83 See Town of Concord v. Boston Edison Co., 915 F.2d 17, 28 (1st Cir. 1990) ("At best, permitting judges and juries to speculate in this area would force regulators continually to revisit prior investment-allocation rules and would discourage regulatory efforts to develop (often with a utility's help) a set of economically rational pricing practices - which, after all, is a common objective of antitrust law and regulation."); see generally I Areeda \& Hovenkamp, Antitrust Law . 
actually makes the relevant decision and supervises the private party it is regulating should antitrust law defer to that decision. Existing case law in the state action doctrine requires that a government agency clearly articulate its rules and actively their implementation; those rules aren't perfect, but they seem a reasonable basis for drawing the distinction we are discussing here. Second, regulatory deference should not apply in situations in which the private party has effectively abrogated the decisionmaking authority of the regulator by making deliberately false statements that were material to the decisionmaking process. ${ }^{84}$ The Unocal case, discussed in Part IV below, falls within that category.

Third, antitrust law should not defer either to regulatory silence or to private action in the shadow of a regulatory structure. Where the government has not affirmatively decided to pursue an anticompetitive course, or where the cause of competitive harm is not government action at all but private action that takes advantage of a set of regulatory rules, antitrust has an important role to play.

These principles preserve the complementary relationship between antitrust law and regulation. They respect the role of regulators within their jurisdiction, while maintaining antitrust courts as the stewards of competition when regulators are unable or unwilling to serve that function. The need for antitrust oversight becomes particularly acute when the regulatory scheme itself creates opportunities for exclusionary conduct - a phenomenon that we call regulatory gaming.

84 See, e.g., Armstrong Surgical Center, Inc., v. Armstrong County Memorial Hosp., 185 F.3d 154 (1999); FTC opinion in UnoCal case at 20 ("Misrepresentation ... undermines this line of analysis by blurring the distinction between private and governmental conduct. Misrepresentation undermines the government's ability accurately and meaningfully to assess public benefit; it vests control over the outcome in the private purveyor of false information."). 


\section{Regulatory Gaming and the Case for Antitrust Intervention}

We define regulatory gaming as behavior that abuses a neutral or pro-competitive regulatory structure and wields it as a tool to accomplish exclusionary results. The notion of "abuse" is critical: we are not talking about ordinary government petitions, even those that are motivated by anticompetitive animus. Abuse involves private conduct that distorts the regulatory process, rather than petitioning behavior designed to influence it. ${ }^{85}$ In many cases of gaming, regulators either do not have the tools to detect and address the exclusionary behavior at issue, or they can do so only after the fact, through tepid ex post responses that do nothing to deter the next round of games. In comparison, antitrust law offers important advantages: it's flexible, it allows courts to look at the big picture and detect patterns of exclusionary behavior, and the heft of its penalties can deter future misconduct.

In this section, we explore three different forms of regulatory gaming, and consider the role of antitrust law in reviewing the gaming behavior. Each of our examples has two characteristics: first, a regulatory framework that determines certain industry characteristics (such as price or entry); and second, private conduct that usurps the intended function of that framework and converts it into an instrument to suppress competition. In all three cases, we contend that antitrust law has a role to play in evaluating the legality of the defendant's acts. This does not mean that the behavior is always condemned; antitrust law's own internal limits will often bar a successful claim. Indeed, in our third example - the price squeeze - we suggest

85 This is not to say that petitioning behavior can never qualify as gaming. As the Unocal case illustrates, see infra text at notes ___ , parties can manipulate a regulatory process by using deception or misrepresentation to achieve exclusionary outcomes, and the law should not immunize such conduct any more than it immunizes sham litigation, see California Motor Transport Co. v. Trucking Unlimited, 404 U.S. 508, 512 (1972), or the knowing attempt to enforce a patent procured by fraud, Walker Process Equipment, Inc. v. Food Machinery \& Chemical Corp., 382 U.S. 172 (1965). 
that plaintiffs should rarely prevail. Our point is simply that antitrust law should determine the outcome of these cases. It makes no sense to dismiss them merely because a regulator has a finger in the pudding. The persistence of regulatory gaming, its presence across a variety of regulated industries, and the threat it can pose to competition across our economy suggest that the generalized standards of antitrust law have an important role to play in curbing this marketdistorting phenomenon.

\section{A. Pharmaceutical product-hopping}

The pharmaceutical industry presents a perfect storm for regulatory gaming. The regulator - the Food and Drug Administration ("FDA") - controls product entry through a complex set of regulations that feature lag time, periods of market exclusivity, and patents whose validity and scope are often the subject of lengthy and contentious litigation. And while Congress placed the ultimate goal of generic entry front and center in the FDA's drug approval framework, the agency itself has neither the mandate nor the power to take competition concerns into account in approving particular pharmaceutical products. Each of these regulatory features creates an opportunity for unscrupulous drug manufacturers to game the system in a way that extends their manufacturing exclusivity, to the detriment of competitors and the public. As a result, pharmaceutical gaming has taken many forms over the years. ${ }^{86}$ This section explores one of its more recent incarnations - pharmaceutical "product hopping."

Product hopping takes advantage of the lag times inherent in the FDA's generic approval process. Generally, to introduce a new drug to market, a pharmaceutical company must provide

86 E.g., Valley Drug v. Geneva Pharmaceuticals, Inc., 344 F.3d 1294 (1 ${ }^{\text {th }}$ Cir. 2003) (rejecting, on substantive antitrust grounds, a challenge to a "reverse settlement agreement," in which a patent-holder paid a generic firm to stay out of its market). 
direct evidence of its safety and efficacy; ${ }^{87}$ upon approval, it must also provide a listing of any relevant patents in the FDA's "Orange Book." ${ }^{\prime 88}$ The Hatch-Waxman Act, which Congress passed in 1984, expedites the approval process for generic follow-on drugs. ${ }^{89}$ Rather than submitting full safety and efficacy data, a generic manufacturer can obtain FDA approval by filing an Abbreviated New Drug Application ("ANDA"), certifying the bioequivalence between its generic and an existing branded drug. ${ }^{90}$ The statute requires the FDA to complete its review within 180 days, but the process often takes longer. ${ }^{91}$ Once approved, the generic receives an "AB-rating," which allows pharmacists to substitute the generic when presented with a prescription for the branded product. ${ }^{92}$

87 Between animal testing, clinical trials, and FDA approval, the process for new drug approvals can take up to ten years. See Judy Vale, Note: Expanding Expanded Access: How the Food and Drug Administration Can Achieve Better Access to Experimental Drugs for Seriously Ill Patients, 96 Geo. L.J. 2143, 2169 \& n.212 (2008).

8821 U.S.C. $\S 355(\mathrm{~b})$. The Orange Book (officially entitled "Approved Drug Products with Therapeutic Equivalence Evaluations" but nicknamed for the color of its cover) provides a comprehensive listing of all drugs approved by the FDA. See http://www.fda.gov/cder/ob/ (electronic version of Orange Book).

89 Drug Price Competition and Patent Term Restoration Act, 21 U.S.C. $\S 355$.

9021 U.S.C. $\$ 355(j)$. Because they lacked the resources to perform clinical trials, small generic drug makers found it difficult to meet the pre-Hatch-Waxman safety and efficacy requirements. Thus, very few generics were available even for drugs whose patents had expired. See David A. Balto, Pharmaceutical Patent Settlements: The Antitrust Risks, 55 Food \& Drug L.J. 321, 325 (2000). The Hatch-Waxman Act improved things considerably, leading to a 150\% increase in the market share of generics between 1984 and 1998. See Congressional Budget Office, How Increased Competition From Generic Drugs Has Affected Prices and Returns, The Pharmaceutical Industry 1 (July 1998).

9121 U.S.C. $\$ 355(\mathrm{j})(5)(A)$; see Department of Health \& Human Services, The Food \& Drug Administration's Generic Drug Review Process, avail. at http://oig.hhs.gov/oei/reports/oei-0407-00280.pdf (noting that FDA review process for ANDAs often exceeds the 180-day statutory maximum).

92 As a general matter, state laws authorize such substitution, and payors (such as insurance companies, HMOs, and government agencies) decide whether to allow or mandate substitution for their covered patients. As the price of branded drugs continues to escalate, more and more insurers and other parties require generic substitution when available. See Milt Freudenheim, 
While the bioequivalence certification addresses the FDA's safety and efficacy

requirements, it does not necessarily qualify the generic to enter the market: the product may be covered by a patent. The Hatch-Waxman Act therefore requires generic manufacturers to identify any patents potentially relevant to their ANDA. ${ }^{93}$ If a patent is listed and unexpired, the generic manufacturer must certify either that its product does not infringe the patent, or that the patent is invalid. ${ }^{94}$ It must also notify the patentee immediately, after which the patentee has 45 days to sue for infringement. ${ }^{95}$ If the patentee sues, it gets an automatic 30-month stay of the ANDA application. ${ }^{96}$ The FDA has no discretion to quicken this stay, nor can a judge shorten it through preliminary relief. According to the statute, only a final court judgment of noninfringement or invalidity can truncate the thirty-month wait. ${ }^{97}$ As Lemley and others have pointed out elsewhere, "The effect of this rather remarkable rule is to delay drug price competition for several years even when a patent is clearly invalid, by granting what is akin to an

Medicare Plans Affected by Rising Drug Costs, N.Y. Times, April 19, 2008, at http://www.nytimes.com/2008/04/19/business/19specialtyside.html (noting rising costs of drugs for elderly patients, and the effect on the federal budget).

93 Id. $\S 355(\mathrm{j})(2)(\mathrm{A})(\mathrm{iv})$. More specifically, the Hatch-Waxman Act requires certification that the drug falls within one of the following categories: (I) no relevant patent is listed in the Orange Book; (II) the patent listed in the Orange Book is expired; (III) the ANDA only seeks approval after the expiration date of the patent listed in the Orange Book; or (IV) the ANDA does not infringe the patent listed in the Orange Book, or the patent is invalid.

94 Id. $\S 355(\mathrm{j})(2)(\mathrm{A})(\mathrm{vii})$. The Hatch-Waxman Act offers a special bonus to the first generic manufacturer to file a Paragraph IV certification for a branded drug. If the first filer succeeds with its paragraph IV application - because of non-infringement, invalidity, or otherwise - it receives a 180-day head start before other generics can enter the market. Id.

$95 I d . \S 355(\mathrm{j})(2)(\mathrm{B}),(\mathrm{j})(5)(\mathrm{B})(\mathrm{iii})$. In its notice to the patentee, the generic must explain in detail the reason that it believes the patent invalid or not infringed.

96 Indeed, the stay can be longer than 30 months, depending on when the generic files its Paragraph IV certification. See Hemphill, supra note _, at 1566 n. 50. And a judge does have power to truncate the stay if either party fails to cooperate in the litigation. See id..; 21 U.S.C. $\S$ $355(\mathrm{j})(5)(\mathrm{B})(\mathrm{iii})$.

9721 C.F.R. $\S 314.107(b)(3)$. 
automatic preliminary injunction whenever a pharmaceutical patent owner files suit against a generic manufacturer." 98

Creative patent-holders have found several ways to convert this regulatory framework into an exclusionary tool. Before 2004, firms could extend their exclusivity for a product almost indefinitely, by adding new patents to their Orange Book filings and stacking up consecutive 30month stays. ${ }^{99}$ After Congress corrected that particular problem, crafty firms took a different tack: rather than stacking patents, they stacked products - making trivial changes to their product formulation and pulling the old drug from the market. This "product-hopping" delays generic competition in two ways. First, like the earlier forms of evergreening, product-hopping can prompt a whole new set of Orange Book filings, ANDA paragraph IV certifications, and litigation-triggered 30-month stays. Second, even without new patent claims, product-hopping delays generic substitution for the new branded product, because the generic firm must file a second ANDA, which faces the same lengthy FDA review as the first one. ${ }^{100}$

\footnotetext{
98 Herbert Hovenkamp et al., IP and Antitrust $\S 12.4 \mathrm{c}$ at 12-43 (2005 Supp.).

99 In Apotex, Inc. v. Thompson, 347 F.3d 1335 (Fed. Cir. 2003), for example, the drug manufacturer had originally named a single patent in its Orange Book listing for a pioneer drug. In response to a generic's ANDA and Paragraph IV certification, the manufacturer sued for patent infringement, thus triggering an initial 30-month stay. While that lawsuit was pending, the manufacturer obtained additional patents, which it added to its Orange Book listing and used as the basis for yet another lawsuit and stay. Remarkably, while that lawsuit was pending, the firm listed three additional patents in its Orange Book listing for the same drug, thereby triggering yet another round of notice, lawsuit, and 30-month stay. See also In re Buspirone Antitrust Litigation, 185 F. Supp. 2d 363 (S.D.N.Y. 2002).

Congress passed legislation in 2003 to eliminate this particular form of patent "evergreening." The new law limits patentees to a single 30 -month stay for any given drug, regardless of how many patents it may list in the Orange Book. 21 U.S.C. $\S 355(\mathrm{j})(5)(\mathrm{b})$. See Hovenkamp et al., supra note _, at $\S 12.4 \mathrm{c}$.

100 The generic firm may, of course, continue to offer the first drug, for which it already gained approval. That means nothing, however, if the branded firm has pulled that drug from pharmacy shelves and convinced doctors to write scripts for its new product. Until the ANDA for that new
} 
The defendant in Abbott Laboratories v. Teva Pharmaceuticals USA, Inc., ${ }^{101}$ capitalized on both of these forms of delay. The case involved Abbott's sale and manufacture of fenofibrate, a drug used to treat high triglyceride levels. The saga began in 1998, when Abbott first received approval of its NDA for a capsule form of fenofibrate, which it marketed under the TriCor brand. The next year, Teva filed an ANDA, seeking approval to sell a generic version of TriCor and certifying that its product did not infringe any valid or enforceable patents. Abbott responded with an infringement suit, which triggered the automatic 30 -month stay. ${ }^{102}$ The judge in the patent suit ultimately agreed with Teva that its product did not infringe, but because Abbott appealed to the Federal Circuit (a losing, but effectively time-consuming, expedition), Teva had to wait almost two years for its final judgment. ${ }^{103}$

In the meantime, Abbott lost little time in devising a strategy to fend off the impending competition from Teva. While the capsule litigation was pending, Abbott submitted an NDA for a tablet formulation of the same drug. The "new" product had a different dosage and listed a new indication, ${ }^{104}$ but reflected no apparent advances over the capsule version; indeed, Abbott asserted the bioequivalence of the two products in its NDA, and relied on its capsule data to

product is approved (with its AB-rating), state laws limit pharmacists' ability to substitute the "old" generic for the "new" branded drug.

101432 F. Supp. $2 d 408$ (D. Del. 2006). To the extent it is relevant, Mark Lemley represents Impax, the antitrust plaintiff in this case.

102 Id. at 416.

${ }^{103} I d$.

104 Abbott's tablet NDA claimed that the drug could increase levels of "good cholesterol." Id. at 416. In support of that claim, however, Abbott submitted data for the capsule formulation, and claimed that it was bioequivalent to the new tablets. $I d$. The new indication therefore did not arise from any new utility conferred by the tablets; to the contrary, Abbott's own documents suggested that the capsule form would have supported the same new indication. 
support its safety and efficacy claims. ${ }^{105}$ As soon as the FDA approved the tablet - and before final resolution of the capsule claim - Abbott launched its TriCor tablets and took extraordinary measures to terminate all possible sales of the capsule form. ${ }^{106}$

Abbott's capsule-tablet switch effectively prevented Teva from penetrating the fenofibrate market. Because pharmacists could not substitute Teva's product for the current version of TriCor - and could not even fill prescriptions for the earlier capsule form - Teva's sales were limited to those doctors who wrote prescriptions specific to Teva's own (Lofibra) brand of the product. Like most generic manufacturers, however, Teva's low-cost business model depended centrally on the ability to substitute for a branded drug, so its sales were, at best, "modest."107

The capsule-tablet switch also, predictably, ushered in the next round of the cat-andmouse game. After Teva filed an ANDA for a generic substitute for the TriCor tablet, Abbott filed new patent infringement suits, which triggered yet another 30-month stay. ${ }^{108}$ And while that litigation was pending, Abbott changed its formulation yet again, reducing the tablet dosage,

105 Id.

106 Abbott not only stopped selling the capsules, but it also bought all existing stock from pharmacies and changed the code for TriCor capsules in the National Drug Data File to "obsolete." "Changing the code to 'obsolete' removed the TriCor capsule drug formulation from the NDDF, which prevented pharmacies from filling TriCor prescriptions with a generic capsule formulation." Id.

107 Branded drug companies, of course, view this business model as a form of free riding, because the generic gets the benefit of the branded firm's investment in marketing and promotion. Generic competition, however, does not occur until after the pioneer drug has had several years of exclusivity in the market. And the government has clearly come down on the side of generic substitution, and for good reason: drugs are much cheaper and more widely available today than they were before the passage of the Hatch-Waxman amendments encouraging generic competition. All competition is in some sense "free riding," but that does not mean it is or should be forbidden. See generally Mark A. Lemley, Property, Intellectual Property, and Free Riding, 83 Tex. L. Rev. 1031 (2005).

108 Abbott, 432 F. Supp. 3d at 417. This time, Teva responded with an antitrust counterclaim, contending that Abbott's product switches violated Section 2 of the Sherman Act. Id. 
filing a new NDA, and abandoning the former product as soon as it obtained regulatory approval. $^{109}$

Abbott may have had compelling reasons for its serial product changes beyond the most obvious one of foreclosing competition. If so, then antitrust doctrine requires courts to defer to Abbott's choices, regardless of their competitive effect. ${ }^{110}$ If, however - as Teva alleged in its antitrust suit - Abbott made the changes specifically to fend off competition from generics, then it succeeded in harnessing the regulatory framework to preserve its exclusivity for several lucrative years. ${ }^{111}$ In light of this obvious anticompetitive harm, the district court in Abbott Labs found Teva's antitrust allegations sufficient to survive a motion to dismiss. ${ }^{112}$

109 Just as it did with the capsule/tablet change, Abbott pulled existing stock from shelves and revised the NDDF code to make the old tablet version obsolete. Id. at 418. Abbott did identify one arguable difference between the new and old tablets: in its NDA, it sought a label change stating that the new tablets no longer had to be taken with food. Teva alleged, however, that the change was made not to improve product efficacy, but only to prevent generic substitution. Id. at 418. And once again Abbott relied on its original safety and efficacy data from the pre-hop formulation, not on new studies, to support the "no food" designation.

110 As the D.C. Circuit has explained:

As a general rule, courts are properly very skeptical about claims that competition has been harmed by a dominant firm's product design changes. See, e.g., Foremost Pro Color, Inc. v. Eastman Kodak Co., 703 F.2d 534, 544-45 (9 ${ }^{\text {th }}$ Cir. 1983). In a competitive market, firms routinely innovate in the hope of appealing to consumers, sometimes in the process making their products incompatible with rivals; the imposition of liability when a monopolist does the same thing will inevitably deter a certain amount of innovation.

United States v. Microsoft Corp., 253 F.3d 34, 65 (D.C. Cir. 2001).

111 Teva filed its first ANDA in 1999, and as of this writing, the FDA does not list a generic equivalent for the most recent tablet formulation. See www.accessdata.fda.gov.

112432 F. Supp. $2 d$ at 422-24. A group of states has also sued Abbott in connection with the TriCor product changes, and the FTC has launched an official investigation into Abbott's behavior. See State of Florida et al., v. Abbott Labs., No. (D. Del. Complaint Filed March 18, 2008); see generally Shirley S. Wang, TriCor Case May Illuminate Patent Limits, Wall St. J., June 2, 2008, at B1. The court recently denied Abbott's motions for summary judgment, and the case is now set for trial. 
Abbott is not alone in finding exclusionary opportunities in the FDA's drug approval framework. In FTC v. Warner Chilcott Holdings, ${ }^{113}$ the FTC alleged that Warner Chilcott attempted a similar scheme with its birth control drug, Ovcon. In the months before approval of a generic ANDA, Warner Chilcott's executives hatched a strategy to switch from pill to chewables to prevent generic substitution. When a delay in its NDA approval threatened to spoil its product-hopping plan, Warner Chilcott simply bought off the generic. ${ }^{114}$ While the FTC's legal claims focused on this agreement rather than the product-hopping issue, the case shows that product-hopping happens, and that Abbott Labs was not an isolated case.

Pharmaceutical product-hopping presents a paradigmatic case of a regulatory game. Without the FDA's product approval framework, generic firms could quickly go to market with competing versions of branded drugs upon expiration of a patent - or even earlier, when they have confidence that their product does not infringe any valid patent on the drug. ${ }^{115}$ But the lengthy product approval process - combined with the two-and-a-half year automatic stay that follows any patent suit - acts as a barrier to such competition. While that barrier may, in the ordinary course, be a necessary cost of accommodating patent rights and health and safety concerns, ${ }^{116}$ product-hopping exploits it precisely because of its exclusionary effects and

1132005 WL 3439585 (D.D.C. Complaint Filed Nov. 7, 2005).

114 Id. at 9 (noting letter of intent, in which Warner Chilcott would pay Barr (the generic manufacturer) \$20 million in exchange for Barr's agreement not to compete in the United States for five years after receiving final FDA approval).

115 The generic in such a case might well face a patent infringement suit, but to obtain an injunction against sale of the drug, the branded manufacturer would have to prove a substantial likelihood of success on its infringement claims. Under the current framework, the "injunction" is automatic, and bears no relation to the merits of the patent claim.

116 We are skeptical that the 30-month automatic stay - with no judicial discretion to override it in lawsuits of questionable merits - is necessary, but our point here is that the stay may serve a legitimate function in some cases but creates an opportunity for abuse in others, and that such abuse should be actionable under antitrust laws. 
converts it into a tool for suppressing competition. Making matters worse, the regulators in these cases can do nothing to thwart this obvious abuse of their administrative function. And while Congress, the FDA, or states could theoretically address the problem prospectively by allowing generic substitution across formulations, ${ }^{117}$ such an ex post solution would neither compensate for past harm, nor deter new variations of the regulatory game.

From an antitrust perspective, product-hopping to ward off generic competition is precisely the sort of behavior the Sherman Act condemns. ${ }^{118}$ While monopolists have no general duty to help their competitors, they do have an obligation to refrain from acts that have no purpose but to exclude competition. ${ }^{119}$ And while distinguishing between the two can be tricky, courts have proven themselves up to the task, even in cases involving product design. ${ }^{120}$ It

117 See Guy V. Amoresano, Branded Drug Reformulation: The Next Brand vs. Generic Antitrust Battleground, 62 Food \& Drug L.J. 249, 256 (2007) ("It may be that a more appropriate approach to the issues raised by reformulation strategies is to leave it to FDA and the state legislatures to determine if some modification of FDA "AB rating" guidelines and state DPS Laws is prudent to address scenarios in which inconsequential reformulations affect the speed of generic drug market entry."). Such an approach would raise challenges of its own, such as how to treat substitutions between products with the same active ingredients but different dosages.

118

"The offense of monopoly under $\S 2$ of the Sherman Act has two elements: (1) the possession of monopoly power in the relevant market and (2) the willful acquisition or maintenance of that power as distinguished from growth or development as a consequence of a superior product, business acumen, or historical accident."

United States v. Grinnell Corp., 384 U.S. 563, 570-71 (1966).

119 See id. (condemning behavior that "was done plainly and explicitly for a single purpose" of driving out competitors); see also United States v. Microsoft Corp., 253 F.3d at 65 ("Judicial deference to product innovation ... does not mean that a monopolist's product design decisions are per se lawful.").

120 Microsoft, 253 F.3d at 65-67 (balancing anticompetitive effect of design choices against business justifications offered by defendant). 
makes no sense to immunize patently anticompetitive behavior because of the risk that some cases might prove tough to decide.

The district court in the Abbott case - following the analytical structure established in the D.C. Circuit's Microsoft opinion - outlined what we view as a reasonable approach to the product-hopping problem. ${ }^{121}$ Most significantly for our purposes, the court applied antitrust law to the gaming behavior, rather than washing its hands of the case because of its regulatory context. On the merits, the court applied the rule of reason, first requiring plaintiffs to show that the defendant's product changes had anticompetitive effect. ${ }^{122}$ The court held that plaintiffs had met their burden (at least in the context of a motion to dismiss) by alleging that Abbott's change in formula, paired with its abandonment of the old drug, blocked plaintiffs from "their costefficient means of competing in the pharmaceutical drug market,"123 thereby harming both plaintiffs and consumers. The court suggested that defendants could rebut the showing of competitive harm by establishing a valid business reason for the behavior. ${ }^{124}$ "[I]f such a justification were offered, the plaintiff could rebut it or, alternatively, establish antitrust liability by demonstrating that 'the anticompetitive harm of the conduct outweighs the procompetitive benefit.",'125

121 Abbott, 432 F. Supp. 2d at 422 (citing Microsoft, 253 F.3d at 66-67).

122 Id. ("Plaintiffs are not required to prove that the new formulations were absolutely no better than the prior version or that the only purpose of the innovation was to eliminate the complementary product of a rival. Rather, as in Microsoft, if Plaintiffs show anticompetitive harm from the formulation changes, that harm will be weighed against any benefits presented by Defendants.").

123 Id. at 423.

124 Id. at 422.

125 Id. (quoting Microsoft, 253 F.3d at 59, 67). See generally Hovenkamp, Janis \& Lemley, supra note _, at $\S 12.3$; William Kolasky, Reinvigorating Antitrust Enforcement in the United States: A Proposal, 22 Antitrust 85, 88-89 (2008) (suggesting a "sliding scale" framework for weighing pro-competitive and anti-competitive effects in rule of reason cases). 
The Abbott opinion leaves open some important questions of antitrust doctrine. The court does not, for example, explain how a fact-finder should go about balancing the pro- and anticompetitive effects of a change in formula. Nor does the court resolve whether a change in formula alone, unaccompanied by the shelf withdrawals and other evidence of exclusionary intent in Abbott, would suffice to state a monopolization claim. ${ }^{126}$ These questions, we believe, require case-by-case resolution, just as any rule of reason balancing inquiry does. Our goal here is not to settle those questions, or to suggest that they will prove easy in close cases. Our claim is that these are antitrust questions, to be addressed as a matter of antitrust law. Product hopping illustrates just how effectively firms can manipulate the FDA's regulatory system, and the extraordinary impact that their behavior can have on competition in drug markets. If a pharmaceutical company designs its products for the sole purpose of dragging out a regulatory process for years and thereby forestalling competition, it has engaged in exclusionary behavior that harms consumers. The fact that it has done so by taking advantage of a loophole in the regulatory scheme does not mean that the FDA has blessed this anticompetitive behavior or that antitrust law must get out of the way to avoid interference in the regulatory scheme. Product hopping is thus one example of a dangerous, market-distorting regulatory game, and a reason that antitrust courts should continue to pay attention to regulated markets.

\section{B. Industry capture of government standard-setting: Unocal}

126 The court in Walgreens v. Astrazeneca Pharmaceuticals L.P., 534 F. Supp. 2d 146 (D.D.C. 2008), rejected a product-hopping antitrust claim based, in part, on the fact that the defendant in that case had not pulled its earlier product from the market after it introduced a new formulation. See id. at _ ("here, there is no allegation that AstraZeneca eliminated any consumer choices[; r]ather, AstraZeneca added choices"). Because the defendant continued to sell the old product, the generic in that case could take advantage of generic substitution laws, so the competitive harm alleged in Abbott was largely absent in Walgreens. 
In pharmaceutical product-hopping, the gaming party uses product manipulation to convert neutral product approval rules into tools to exclude entry. Another form of gaming achieves its anticompetitive goals through direct manipulation of the regulatory process - the use of deceit or other misconduct to obtain regulatory outcomes that favor the gaming firm. ${ }^{127}$ Like product-hopping, these cases raise tough questions, and require courts to strike a tricky balance between regulatory deference and antitrust intervention. The questions here are tougher than in product-hopping, because the anticompetitive conduct involves the participation (albeit unwitting) of a regulatory agency itself. In particular, the Noerr-Pennington doctrine forbids antitrust review of some forms of government petition, even when they may mislead. ${ }^{128}$ The doctrine does not, however, require abstention in all cases at all times. ${ }^{129}$ In particular, when an agency explicitly relies upon misleading factual submissions by a regulated party, and those

127 The recent Discon case provides another example of this sort of regulatory game. The regulated party in that case engaged in a kickback scheme to deceive regulators into believing that its costs were higher than they really were; the regulators relied on the party's submissions and approved inflated regulated rates; and consumers footed the bill. Nynex Corp. v. Discon, Inc., 525 U.S. 128 (1998). The Supreme Court appeared almost scornful of the idea that the regulatory fraud could form the basis for an antitrust complaint, declaring that " $[t] \mathrm{o}$ apply the per se rule here - where the buyer's decision, though not made for competitive reasons, composes part of a regulatory fraud - would transform cases involving business behavior that is improper for various reasons, say, cases involving nepotism or personal pique, into treble-damages antitrust cases." Id. at 136-37. Because Discon involved a very precise legal question, however - the question of whether to apply per se analysis to the alleged boycott in that case - the Court's dismissive language does not necessarily preclude a rule of reason claim based on the same set of facts, but with proof of market power or adverse market impact. See id. at 135 ("the specific legal question before is us whether an antitrust court considering an agreement by a buyer to purchase goods or services from one supplier rather than another should (after examining the buyer's reasons or justifications) apply the per se rule if it finds no legitimate reason for that purchasing decision").

128 Eastern RR Presidents Conference v. Noerr Motor Freight, Inc., 365 U.S. 127, 136, 140-41 (1961).

129 See BE\&K Const. Co. v. N.L.R.B., 536 U.S. 516, 525-26 (2002) ("while genuine petitioning is immune from antitrust liability, sham petitioning is not"). 
submissions materially affect an agency decision that turns out to have exclusionary effects, antitrust law can and does have something to say.

The FTC v. Unocal case epitomizes this form of gaming. ${ }^{130}$ Unocal involved misrepresentations made to the California Air Resources Board ("CARB”), a state agency charged with reducing fuel emissions. In the late 1990s and early 2000s, CARB conducted a rulemaking process to develop specific, stringent standards for low-emissions gasoline. Unocal participated actively in the rulemaking process, advocating a set of standards that closely resembled the ones ultimately adopted by CARB. ${ }^{131}$ In its submissions to the agency, Unocal never mentioned that it owned patent rights over the standards; indeed, it repeatedly touted their "flexibility" and "cost-effectiveness," and suggested that it had relinquished any proprietary interest that it might have once had in the standards. ${ }^{132}$ In reliance on these representations, CARB adopted the standards, and refiners invested billions of dollars to comply with them. Only then, according to the FTC, did Unocal disclose its newly-minted patents and demand royalties for the use of the technology. ${ }^{133}$

Like Abbott's product manipulation, Unocal's misrepresentations effectively converted a neutral regulatory process into an exclusionary tool. The purpose of the CARB proceedings was to define a standard that would enable the production of cost-effective, environmentally sensitive fuels - not to give market power to one individual party. Yet Unocal's misrepresentations turned

130 See Opinion of the Commission, In re Matter of Union Oil Company of California, Docket No. 9305 (opinion issued July 7, 2004), avail. at http://www.ftc.gov/os/adjpro/d9305/040706commissionopinion.pdf. For the complete filings and rulings in the case, see http://www.ftc.gov/os/adjpro/d9305/index.shtm.

131 Id. at 3-5.

132 Id. at 3-4.

133 Id. at 6. The complaint also alleges that Unocal tweaked its patent applications during prosecution to match more closely with the emerging state standard. Id. 
the regulators into unwilling (and unknowing) participants in a scheme to vest Unocal with just such power. According to the FTC, if CARB had known about Unocal's patent rights, it would have either adopted different standards, or insisted on more favorable terms of access to the standards by competitors. ${ }^{134}$ In other words, the misrepresentations reflect "willful acquisition or maintenance" of power in the fuel market - the very definition of an antitrust breach. ${ }^{135}$ From a consumer welfare perspective, the behavior caused just the kind of harm that antitrust laws seek to prevent - a structural barrier that will inevitably raise prices and cause inefficiently low production in the relevant market. Indeed, the fact that Unocal's conduct was directed to a state agency made competitive harm all the more likely. Other cases have considered misrepresentations to private standard-setting organizations, ${ }^{136}$ those representations can facilitate monopolization of an industry, but only if they end up locking an industry into a standard that turns out to be patented. Market participants in private standard-setting organizations can choose not to adopt the standard. By contrast, no gasoline company can choose to ignore the CARB standard for reformulated gasoline; if Unocal's misrepresentations or omissions in fact caused the adoption of that standard, companies that want to sell gasoline in California had no choice but to pay Unocal whatever they demanded.

Despite these obvious competitive harms, some courts might hesitate to impose liability based on the Unocal version of regulatory gaming, for two reasons. First, the Noerr-Pennington doctrine, which insulates certain government petitions from antitrust liability, might give courts pause, since Unocal's anticompetitive conduct involved petitioning the government. Second, a

134 Id. at 5.

135 United States v. Grinnell Corp., 384 U.S. 563, 570-71 (1966).

136 Rambus Inc. v. F.T.C., 522 F.3d 456 (D.C. Cir. 2008); Broadcom Corp. v. Qualcomm Inc., 501 F.3d 297 (3d Cir. 2007). 
recent decision of the D.C. Circuit casts doubt on the FTC's second theory of harm in Unocali.e., that an antitrust violation can lie based on misrepresentations that lead to a higher price in the market, rather than changing the standard itself. We think the first of these concerns requires careful attention to the facts, but in a case like Unocal does not justify antitrust abstention. The second concern is not an argument for abstention at all, but instead a substantive claim that there is no competitive harm in a case like this - a claim of which we are dubious.

\section{Noerr-Pennington and regulatory games}

Under the Noerr-Pennington doctrine, "[t]hose who petition the government for redress are generally immune from antitrust liability. ${ }^{\prime 137}$ The principle applies to all sorts of petitions directed at any branch of government, ${ }^{138}$ and derives from two basic tenets: first, that Congress cannot have meant for the Sherman Act to impair citizens' right to participate in our representative democracy; ${ }^{139}$ and second, that the First Amendment would, in any event, bar such

137 Professional Real Estate Investors, Inc. v. Columbia Pictures Indus., 508 U.S. 49, 56 (1993).

138 See Eastern RR Presidents Conference v. Noerr Motor Freight, Inc., 365 U.S. 127, 136, 14041 (1961) (applying doctrine to bar claim against railroad consortium based on misleading publicity campaign that was aimed to influence legislation); California Motor Transport Co. v. Trucking Unlimited, 404 U.S. 508 (1972) (holding that Noerr principle applies generally to petitions to administrative agencies); United Mine Workers v. Pennington, 381 U.S. 657 (1965) (invoking doctrine to petition of executive branch officials and administrative agencies).

139 See Noerr, 365 U.S. at 137 ("In a representative democracy such as this, these branches of government act on behalf of the people and, to a very large extent, the whole concept of representation depends upon the ability of the people to make their wishes known to their representatives. To hold that the government retains the power to act in this representative capacity and yet hold, at the same time, that the people cannot freely inform the government of their wishes would impute to the Sherman Act a purpose to regulate, not business activity, but political activity, a purpose which would have no basis whatever in the legislative history of that Act."). 
an interpretation. ${ }^{140}$ The doctrine seeks to distinguish between commercial activities - which the Sherman Act addresses - and political activity, which lies beyond its reach. ${ }^{141}$

The doctrine, however, has limits. Even in Noerr itself, the Supreme Court cautioned that petitioning behavior could lose its protection if it were a "sham to cover what is actually nothing more than an attempt to interfere directly with the business relationships of a competitor ..."142 Since then, the Supreme Court has applied the exception to misrepresentations made to courts and administrative agencies, ${ }^{143}$ including patent infringement suits based on a patent obtained through fraud. ${ }^{144}$ The cases following Noerr seem to distinguish between attempts to influence a legitimate government process, on the one hand, and behavior that shatters the integrity of the process and effectively converts it into a private affair, on the other.

While a full analysis of the Noerr-Pennington exemption falls beyond the scope of this paper, ${ }^{145}$ we think the Noerr-Pennington doctrine must give way when a defendant has co-opted an administrative process through material misstatements or other fraud. When this happens, the

140 See id. at 138 ("The right of petition is one of the freedoms protected by the Bill of Rights, and we cannot, of course, lightly impute to Congress an intent to invade these freedoms.”).

141 Id. at 137; see id. at 140-41 ("Insofar as [the Sherman] Act sets up a code of ethics at all, it is a code that condemns trade restraints, not political activity, and ... a publicity campaign to influence governmental action falls clearly into the category of political activity.").

142 Id. at 144.

143 See, e.g., California Motor Transport Co. v. Trucking Unlimited, 404 U.S. 508, 512 (1972) (finding no immunity when one group of highway carriers "sought to bar ... competitors from meaningful access to adjudicatory tribunals and so to usurp that decisionmaking process" by "institute[ing] ... proceedings and actions ... with or without probable cause, and regardless of the merits of the cases").

144 See Walker Process Equipment, Inc. v. Food Machinery \& Chemical Corp., 382 U.S. 172 (1965).

145 For a thorough analysis of Noerr immunity in the context of agency misrepresentations, see FTC Unocal decision, at http://www.ftc.gov/os/adjpro/d9305/040706commissionopinion.pdf. We generally agree with the FTC's view that Noerr immunity does not apply to "deliberate misrepresentations that substantially affect the outcome of a proceeding or so infect its core to deprive the proceedings of legitimacy ...." FTC Unocal decision at 29. 
defendant is not merely exercising its rights to influence a legitimate government process; it is effectively converting the process into a private vehicle to exclude competition. ${ }^{146}$ As the FTC concluded in Unocal, "deliberate misrepresentations that substantially affect the outcome of a proceeding or so infect its core to deprive the proceeding of legitimacy may not, in appropriate circumstances, qualify for Noerr-Pennington protection."

\section{Evading regulatory limits as antitrust harm}

The second open question is whether antitrust injury occurs when a defendant's misrepresentations prevent an agency from placing limits on an exercise of market power, rather than eliminating the market power altogether. In Rambus v. FTC, ${ }^{148}$ the D.C. Circuit effectively held that where market power resulted from a regulatory decision (there, the grant of a patent), antitrust law could not constrain the price the monopolist charged. Rambus involved alleged misrepresentations made in the course of a private standard-setting organization's deliberations. The FTC claimed that Rambus had withheld material information about patent rights that it held over the relevant technology. The FTC alleged that if the SSO had known about Rambus's patents, either it would have adopted a different standard, or it would have demanded some form of fair and nondiscriminatory licensing terms on Rambus's patents. The D.C. Circuit found the second allegation legally inadequate, concluding that the mere exercise of market power (i.e.,

146 See FTC Unocal decision at 29 ("Clearly, a proceeding fundamentally tainted by misrepresentation lacks the 'genuine' nature that is the hallmark of what the Supreme Court seeks to protect.").

147 FTC decision at 29; see also Herbert Hovenkamp, Federalism and Antitrust Reform, 40 U.S.F. L. Rev. 627, 632-33 (2006) ("antitrust need not countenance restraints in which the effective decision makers are the market participants themselves").

148 Rambus Inc. v. Federal Trade Commission, 522 F.3d 456 (D.C. Cir. 2008). 
charging higher prices) does not violate the antitrust laws if the market power itself arose from a valid government grant. ${ }^{149}$

The Rambus court relied on NYNEX v. Discon, ${ }^{150}$ in which the Supreme Court refused to apply the per se rule to a kickback scheme involving a regulated utility. The regulated party in Discon awarded a contract for non-regulated services to a company that would charge higher prices that the regulated company could then pass on to consumers through rate regulation. The NYNEX Court rejected an antitrust claim alleging that the scheme constituted an unlawful group boycott, absent proof that it harmed competition (not just a competitor) in the non-regulated service market. The Court specifically acknowledged that consumers were injured by the conduct, because it resulted in higher prices in the regulated market. Because that injury came from the exercise of agency-granted market power, however, the Court deemed it beyond the reach of antitrust law. While NYNEX itself involved only the question of whether the per se rule applied, Rambus read it as going further and immunizing any conduct that owed its origin to a regulatory grant of market power.

Both NYNEX and its substantial new extension in Rambus are problematic as matters of antitrust law. The harm to competition in NYNEX did not stem solely from government-granted market power; it stemmed from the defendant's effort to extend that market power in ways that deceived the regulatory agency and prevented it from controlling NYNEX's behavior. Similarly, the harm to competition in Rambus did not stem solely from the government's grant of a patent, but from the combination of that grant with Rambus's deception of a standard-setting organization that would otherwise have restrained the ability of Rambus to charge a

149 Id. at 464 ("But an otherwise lawful monopolist's use of deception simply to obtain higher prices normally has no particular tendency to exclude rivals and thus to diminish competition."). 150525 U.S. 128 (1998). 
supracompetitive price for that patent. Both of these cases, in other words, involve deliberate and effective regulatory gaming. By refusing to apply antitrust law to private deceptive conduct that manipulates a regulatory process, or extends or exacerbates the anticompetitive effects of a regulatory decision, NYNEX and Rambus appear to condone a new and insidious form of implicit antitrust deference to regulation, one in which antitrust law must ignore conduct that exacerbates competitive harm because the company causing that harm wouldn't have been in a position to do so but for regulation. ${ }^{151}$

Whatever one's views of the substantive antitrust issues, the existence of antitrust injury is an antitrust question that should be decided by antitrust courts, and will not (and often cannot) be adequately addressed by regulatory agencies. And neither NYNEX nor Rambus discredits the notion that abuse of standard-setting processes can, in some circumstances, violate the antitrust laws. In particular, if the facts show that an agency relied upon misrepresentations in choosing a standard - and would have chosen a different standard but for the misrepresentations - then the defendant has caused a structural harm in the market even in the narrow Rambus view. In these circumstances, the defendant's misrepresentations are the "but-for" cause of the defendant's

151 Not all courts have taken the same approach to SSO-related misrepresentations. See, e.g., Broadcom Corp. v. Qualcomm Inc., 501 F.3d 297, 316 (3d Cir. 2007) (allowing antitrust claim based on allegations that misrepresentations to SSO either influenced the ultimate standard, or prevented SSO from limiting licensing fees). 
economic monopoly. ${ }^{152}$ While the D.C. Circuit refused to speculate on whether even this could constitute antitrust injury, ${ }^{153}$ it strains credulity to imagine any other outcome.

Like product-hopping, then, abuse of government standard-setting processes can cause competitive harm in markets. And like product-hopping, the harm may not be remediable through administrative recourse. The capture of government standard-setting processes offers yet another example of regulatory gaming, and another reason that antitrust courts should continue to play a role in regulated markets.

\section{The limits of regulatory gaming - price squeezes}

Our final example, the price squeeze, illustrates the limits of antitrust law in addressing gaming behavior. Like the last two examples, a regulatory price squeeze involves manipulation of the regulatory system for anticompetitive ends. But it also often involves behavior which regulators have specifically endorsed, which falls within their core regulatory ambit, and which requires detailed knowledge of both firm and industry economics. In these circumstances, we think the benefits of antitrust intervention begin to fade in comparison with its costs, and courts should tread carefully. While a valid price squeeze claim is theoretically possible, it requires proof of predatory pricing in an unregulated retail market - a showing that is likely to be rare.

152 A patent, of course, confers a right to exclude, but does not necessarily confer power over any relevant market. But when a standard-setting body (private or government) settles on a standard that applies across an industry, and one party holds proprietary rights over that standard, the party does have monopoly power. It follows, then, that if a misrepresentation plays a material role in the selection of a patented standard, the misrepresentation has caused the type of harm to competition that the antitrust laws seek to prevent.

153 See id. at 463 ("We assume without deciding that avoidance of the first of these possible outcomes was indeed anticompetitive; that is, that if Rambus's more complete disclosure would have caused JEDEC to adopt a different (open, non-proprietary) standard, then its failure to disclose harmed competition and would support a monopolization claim.”). 
A price squeeze occurs when a vertically integrated firm with a regulated monopoly in an upstream market that faces competition in a downstream market compresses its wholesale and retail prices to make it impossible for others to compete with it in the downstream (retail) market. ${ }^{154}$ If the wholesale price is high enough and the retail price low enough, competing retailers simply cannot cover their costs, and will be driven from the market. In linkLine v. Pacific Bell, for example, an integrated firm allegedly charged its retail competitors wholesale prices that exceeded its own retail rates. ${ }^{155}$ A competitor obviously could not stay in the market for long when the cost of a single input is higher than the price it can charge consumers for its overall product.

The economics of price squeezes are the subject of some debate. Advocates of a "one monopoly profit" theory contend that price squeezes can cause no harm, because the upstream monopolist cannot raise the price any more by controlling two levels of production than it could by controlling only the upstream market. ${ }^{156}$ Others, however, take issue with the single

154 See generally Areeda \& Hovenkamp 1767C; American Bar Association Section of Antitrust Law, Energy Antitrust Handbook 121-25 (2002) (discussing price squeeze cases). Judge Learned Hand first recognized price squeezes as an antitrust violation in United States v. Aluminum Co. of Am., 148 F.2d 416, 437-38 (2d Cir. 1945).

155 linkLine Communications, Inc. v. SBC California, Inc., 503 F.3d 876 (9th Cir. 2007).

156 See, e.g., J. Gregory Sidak, Abolishing the Price Squeeze as a Theory of Antitrust Liability, 4 J. Comp. Law \& Econ. 279 (2008) ("If an unregulated, vertically integrated firm truly is a monopolist in the supply of the bottleneck input, and if downstream competitors use that input in fixed proportion to their production of the retail product, then the 'one monopoly profit theory' implies that the vertically integrated firm has no incentive to attempt the price squeeze."). The one monopoly profit theory has led to a general skepticism about applying antitrust law to vertical restraints. As described by Judge Posner:

Imagine an industry with two levels, production and distribution: if production is monopolized and distribution is competitive, can the monopolist increase his profits by buying out the distributors? ... If the producer acquires the distributors and increases the retail markup he will have to decrease the producer markup by the same amount. He cannot maximize his profits by charging a price above the monopoly price...." 
monopoly price theory, and contend that monopolists can both increase their profits and insulate their economic power by leveraging their monopoly into related downstream markets. ${ }^{157}$

Whatever the economics of price squeezes more generally, most courts and commentators seem to agree that one form of price squeeze does raise antitrust concerns $-\mathrm{a}$ price squeeze involving predatory prices at the retail level. ${ }^{158}$ In particular, when a monopolist lowers its retail prices to below its relevant measure of costs, it can face claims of predatory pricing like any other established or aspiring monopolist. ${ }^{159}$ Predatory pricing alone can be illegal if the monopolist is likely to be able to recoup its costs. But the existence of a price squeeze by a monopolist can help ensure the success of predation as an exclusionary tactic. And

Richard A. Posner, Antitrust Law: An Economic Perspective 197 (1976); see also Phillip Areeda \& Louis Kaplow, Antitrust Analysis 489 (5 $5^{\text {th }}$ ed. 1997) ("The power already possessed by the ... monopolist to control the price and output ... effectively controls the price and output of independent" downstream firms); Robert Bork, The Antitrust Paradox 229 (2d ed. 1993) ("[A] monopolist has no incentive to gain a second monopoly that is vertically related to the first, because there is no additional monopoly profit to be taken."); $c f$. Charles F. Rule, PatentAntitrust Policy: Looking Back and Ahead, 59 Antitrust L.J. 729, 731 ("[T] monopoly price for any given product, and you can either sell that product alone or you can combine it with as many complements as you want, but you are only going to be able to earn that one monopoly profit.”); GKA Beverage Corp. v. Honickman, 55 F.3d 762, 767 (2d Cir. 1995) ("[A] vertically structured monopoly can take only one monopoly profit...").

157 See, e.g., Pietro Crocioni, Leveraging of Market Power in Emerging Markets: A Review of Cases, Literature, and a Suggested Framework, 4 J. Competition L. \& Econ. 449, 458-69 (2008) (summarizing arguments for and against one monopoly profit theory); $c f$. Roger D. Blair \& David L. Kaserman, Law and Economics of Vertical Integration and Control 124. ThenJudge Breyer laid out the economic arguments for an against price squeezes in Town of Concord v. Boston Edison Co., 915 F.2d 17, 27-29 (1st Cir. 1990); see also Statement of the Federal Trade Commission, Petition for a Writ of Certiorari in Pacific Tel Co. d/b/a AT\&T California v. linkLine Comms., Inc. (No. 07-512), avail. at http://www.ftc.gov/os/2008/05/P072104stmt.pdf.

158 Not all commentators view even predatory price squeezes as problematic. See, e.g., Sidak, supra note

159 See, e.g., Covad Communications Co. v. BellSouth Corp., 374 F.3d 1044, $1050\left(11^{\text {th }}\right.$ Cir. 2004) (holding that price squeezing complaint states an antitrust claim if "the two basic prerequisites for a showing of price predation under $\S 2$ of the Sherman Act are met"); Covad Communications Co. v. Bell Atlantic Co., 407 F.3d 1220, 1222 (D.C. Cir. 2005) (rejecting price squeeze claim, but noting that such a claim may lie if the plaintiff had alleged predatory pricing at the retail level). 
if the monopolist is compensated for its regulated wholesale prices, the fact of regulation can also help the monopolist recoup its losses.

Price squeezes can, depending on the circumstances, involve a regulatory game. Price squeezes can occur in fully regulated markets (with regulated prices at both wholesale and retail levels), partially regulated markets (with regulated wholesale prices, but no regulation at retail), and unregulated markets. And while their use in fully regulated markets probably lies beyond antitrust courts' jurisdiction, ${ }^{160}$ partially regulated price squeezes raise thornier questions. If, for example, a partially regulated firm convinces regulators to approve an unreasonably high wholesale price for an input that it controls, it can easily undercut its retail rivals, who must pay the wholesale price as a part of their cost of production. If the cost-cutting is predatory, the regulated party can effectively drive out its retail competition, which perverts the entire purpose of the wholesale price regulation - ensuring meaningful access to the input for competitors.

Yet even this form of predatory price squeeze raises difficult questions that lie at the very intersection between regulatory deference and substantive antitrust law. In particular, because predatory pricing claims require proof that a defendant priced below its costs, courts must consider the relationship between the regulated wholesale prices and the "appropriate measure" of a defendant's costs. ${ }^{161}$ Should courts treat the regulated prices as an accurate measure of the cost of the regulated input, and assume that retail prices that fall below them are by definition predatory? Should courts instead treat the regulated wholesale price as irrelevant, and require direct evidence of the integrated firm's overall costs? Or, at the other extreme, should courts

160 For reasons discussed more fully below, antitrust courts should not ordinarily second-guess decisions affirmatively made by regulators within their core area of expertise. For fully regulated industries, the fact that the regulator has specifically approved both levels of prices counsels against antitrust intervention.

161 See Brooke Groupe Ltd. v. Brown \& Williamson Tobacco Corp., 509 U.S. 209, 222-23 (1993). 
decide that antitrust laws have no role to play because of the existence of regulation at one level of production?

We can see good reasons to support either of the first two approaches to predatory price squeeze claims. While it seems reasonable to hold producers to what they tell regulators about their accurate measure of cost, the wholesale rates do not necessarily reflect the producer's cost of utilizing the wholesale input internally; it may well cost more to provide it to third parties. ${ }^{162}$ On the other hand, courts may find the regulated rate useful as a benchmark to evaluate the credibility of cost evidence provided by the parties. ${ }^{163}$

The third option, however - complete abdication of antitrust law's role in a partially regulated industry - makes no sense as a matter of law or economic policy. In the (probably rare) case in which an integrated firm engages in true predatory pricing, its behavior can undermine competition in the retail market just like other forms of predatory conduct. Indeed, as with standard-setting, the fact of regulation may make the conduct more problematic than it would be in the absence of regulation, since the monopolist can rely on a government-approved wholesale price to compel payment by retail competitors and therefore to create the price squeeze. And the regulators in these cases have no power to address the exclusionary behavior, because their jurisdiction is limited to the wholesale - rather than the retail - price.

Of course, a predatory pricing claim requires proof of other elements as well - evidence of actual or potential monopoly power in the relevant (in this case, retail) market, as well as a likelihood of recoupment should the scheme succeed in driving competitors from the market. As

162 Indeed, this is the main justification for vertical integration more generally: it often costs less to integrate different operational layers into a single enterprise.

163 Cf. Covad Communications Co. v. BellSouth Corp., 374 F.3d 1044, 1051 (11th Cir. 2004) (holding that relationship between wholesale and retail prices "is a factual matter for the district court to determine at a later stage of proceedings"). 
a result, we think successful predatory price squeeze claims - like predatory pricing claims more generally - are likely to be rare. Their rarity, however, appropriately owes itself to stringent standards of substantive antitrust law, rather than absolute deference to regulators in even partially regulated markets.

The Supreme Court will have an opportunity to reflect on some of these issues this term in Pacific Bell Telephone Co. v. linkLine Communications, Inc. ${ }^{164}$ LinkLine involves an alleged price squeeze in the DSL Internet services market, a partially regulated industry. According to linkLine, Pacific Bell not only compressed its wholesale and retail prices, but for a period, it charged other DSL providers wholesale prices that exceeded the fees charged to retail customers. If true, such a price structure would obviously make it impossible for competitors to buy DSL line access and resell it in competition with Pacific Bell. The Ninth Circuit held these allegations sufficient to state a claim for monopolization. The opinion hedged on a variety of points, including whether predation was necessary to state a price squeezing antitrust claim, ${ }^{165}$ and whether unlawful price squeezes could occur in fully regulated markets. ${ }^{166}$ The Ninth Circuit suggested, without holding, that a valid price squeeze claim might lie even when regulators approved prices at both levels. ${ }^{167}$

164128 S. Ct. 2957 (2008, granting cert.).

165 E.g., linkLine Communications, Inc. v. SBC California, Inc., 503 F.3d 876 (9th Cir. 2007) ("We do not preclude the district court, however, from re-examining the viability of this claim on summary judgment after the record is more fully developed and it is clear whether the complained of behavior took place at the regulated wholesale level, the unregulated retail level, or some combination of the two, and to what extent, if any, the responsible agencies have devoted attention to or had involvement in the complained of conduct.").

$166 I d$. at 883-84 (concluding that viability of price squeeze claim in fully regulated industry turns on the "particular industry and factual setting").

167 The court cited an earlier Ninth Circuit opinion finding price squeeze claims possible in fully regulated markets, depending on the industry setting. See id. 
The Supreme Court could resolve the linkLine case in a number of different ways. It could hold, as a matter of antitrust law, that the allegations in the case were insufficient to state a predatory pricing claim. ${ }^{168}$ It could go further, and hold (as the defendant urges) that price squeeze claims of any stripe are implausible after Trinko. ${ }^{169}$ It could surprise us all and uphold the price squeeze claim based on its (implicit) allegation of predatory retail pricing. Whatever it does, our argument is that the Court should do it as a matter of antitrust law and not blind regulatory deference. The Court will have an opportunity to clarify the relationship between antitrust law and regulation, and we hope it does so in a way that respects the continuing role of antitrust law in regulated industries. That does not mean the plaintiff should win the case; price squeeze claims, like other forms of predatory pricing, are rarely successful. But it does mean that the Court should not avoid the substantive issue altogether by wrongly assuming that the regulated agency can or will solve the problem.

\section{Conclusion}

Regulators cannot, should not, and do not substitute for antitrust courts in ensuring vibrant competitive markets. Indeed, as we have explained in this article, the existence of regulation can sometimes exacerbate, rather than alleviating, the risk of exclusionary behavior in

168 Judge Gould, in his dissenting opinion, contended that the predatory pricing claim failed to allege several critical facts, including the ability to influence prices in the retail market and below-cost pricing. See id. at 886 ("if plaintiffs in good faith cannot allege market power, below cost sales and probable potential for recoupment in the retail market, then the case should not proceed").

169 This argument begins with the premise that Trinko effectively abolished antitrust claims based on unilateral refusals to deal. If a company has (as a matter of antitrust law, anyway) an absolute right to deal or not deal with its competitors, then it has an absolute right to determine the conditions of those deals. 
regulated markets. When parties game a regulatory system to achieve anticompetitive results, antitrust law should apply.

We emphasize that saying antitrust law should scrutinize some forms of private regulatory gaming does not necessarily mean that antitrust law should condemn every type of regulatory gaming. Antitrust law properly balances anticompetitive harm against precompetitive benefits, and it properly balances the risk of false negatives against the risk of false positives. In particular cases, regulatory gaming may implicate precompetitive concerns such as encouraging innovation. ${ }^{170}$ In other cases, regulatory gaming may resemble conduct that is neutral or procompetitive, raising the risk that antitrust enforcement will create false positives. But substantive antitrust law is sensitive - even, perhaps, overly sensitive - to these concerns. They may provide a reason for antitrust courts to tread cautiously in finding defendants liable, but they do not offer a reason for antitrust courts not to ask the hard questions at all.

170 Berkey Photo, Inc. v. Eastman Kodak Co., 603 F.2d 263 (2d Cir. 1979); 1 Hovenkamp et al, IP \& Antitrust, supra note _, at sec. 12.5. 